
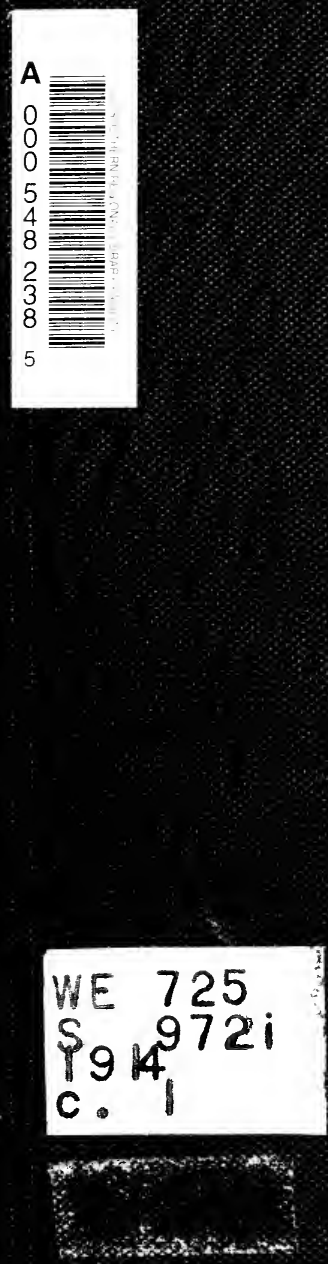


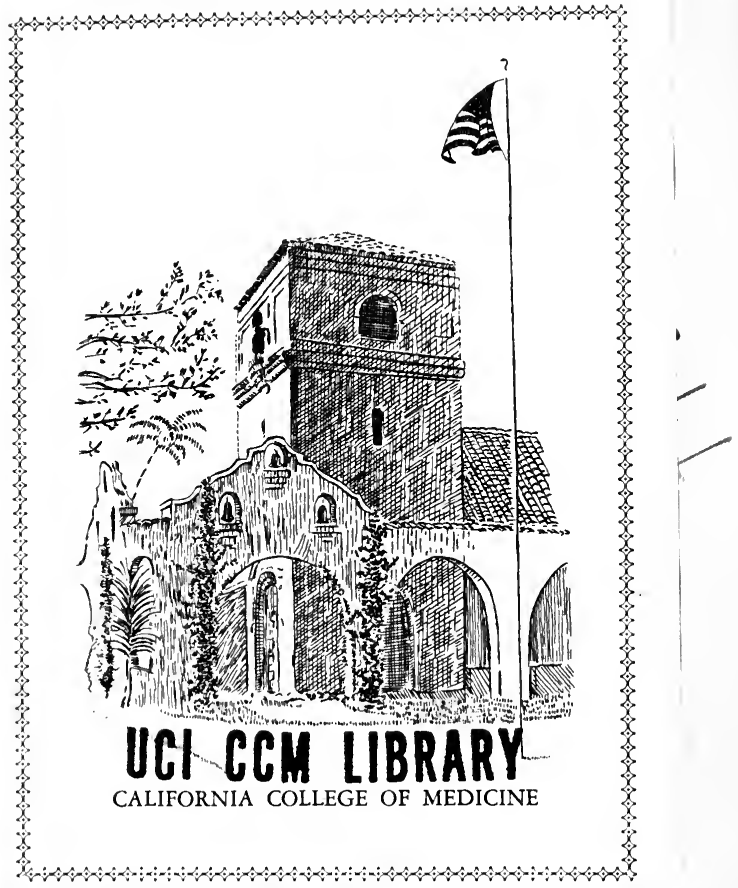




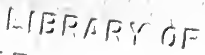

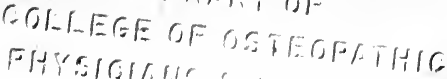

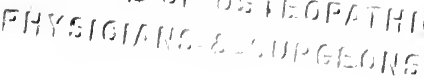$$
\text { (t) }
$$ 


$$
\begin{aligned}
& \text { 70 Y } 949811
\end{aligned}
$$

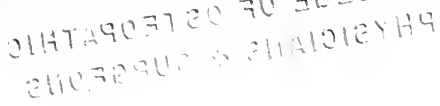




\section{THE \\ INTERVERTEBRAL FORAMEN}

SWANBERG 


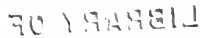

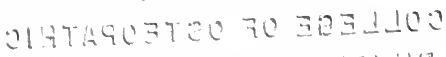

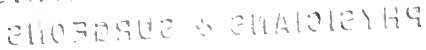




\section{THE \\ INTERVERTEBRAL FORAMEN}

AN ATLAS AND HISTOLOGIC DESCRIPTION

OF AN INTERVERTEBRAL FORAMEN

AND ITS ADJACENT PARTS

BY

HAROLD SWANBERG

Member American Association for the Advancement of Science

WITH AN INTRODUCTORY NOTE

BY

PROF. HARRIS E. SANTEE

Illustrated by 16 full page plates none of which have ever before appeared in print

ChICAGo SCIENTIFIC PÜBLISHING CO.

S. W. Cor. Grace and Osgood Streets

CHICAGO, ILLINOIS 


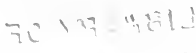

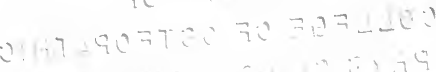

Copyright, 1914

BY

HAROLD SWANBERG

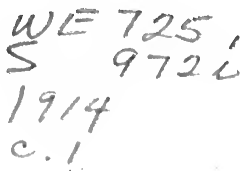

HAMMOND PAESS

W. B. CONKEY COMPANY CNicaoo 


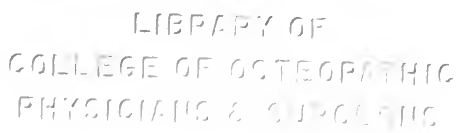

\section{gedicated}

TO THE MEMORY OF MY MOTHER

Lillian Goerz SwaNberg 


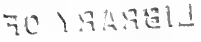

0HATA

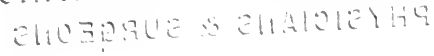




\section{INTRODUCTORY NOTE}

$\mathrm{By}$

HARRIS E. SANTEE, A. M., Ph. D., M. D.

Department of Anatomy, Jenner Medical College and Chicago ColLege of Medicine and Surgery.

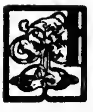

TAKE pleasure in writing an introductory note to the monograph of Mr. Harold Swanberg. Accurate information is always valuable, and it is such that $\mathrm{Mr}$. Swanberg presents. A careful investigation of the intervertebral foramina and their contents is of special interest. Though the field is so limited, it is sufficiently broad to form the anatomic basis for several schools of practice. Mr. Swanberg shows by actual sections the exact relations of the first dorsal nerve at the intervertebral foramen. A study of his work will help to determine whether compression of the nerves at this point is likely to occur; and whether, therefore, there is substantial ground for the doctrine that such compression is the immediate cause of all or of a considerable number of pathologic conditions. 


\section{PREFACE}

橉

HIS atlas is absolutely unique. To the best of the author's knowledge it contains the first photomicrographs and scientific description of an intervertebral foramen that has ever been published. No apology is therefore offered for its appearance. During the past quarter of a century a great deal of attention has been directed to the spinal column from a therapeutical standpoint. Many systems have arisen claiming that the great majority of diseases have their origin from various spinal abnormalities, which result in producing pressure, or other phenomena, to the nerves in the intervertebral foramina. It is not the purpose of this book to discuss any of the pathologic changes which take place to the nerves or the intervertebral foramina, but to present a clear and concise description of the normal histologic structure of this part, with special reference to the relations of the nervous structures. Once the normal structure is mastered, the reader will then be in a better position to judge for himself the effects of pathologic changes to these parts, and can formulate his own opinion about nerve pressure, impingement, irritation, etc., as a cause of disease.

It will be interesting to note how the photomicrographic plates in this book were prepared. First, photomicrographs were taken from the original slides. These were then further enlarged and carefully retouched. The retouched photomicrographs were then all. reduced to an approximately equal diameter and half-tone plates made. At considerable extra expense the best engravers' proving paper was used to reproduce the plates. This renders the detail of the plates as distinct as it is possible to be made, yet every part is shown exactly as it normally occurs.

The Basle anatomical terminology is used throughout, and 
the description of the text is so worded that the reader can understand each plate separately or follow them consecutively.

The author has been greatly interested in spinal therapeutics for many years. The plan of this monograph was conceived in 1910, and after much research and microscopic examinations of various foramina the present description was written.

Inasmuch as this work is original and the failure, after a most careful search, to find any literature on the structure of the intervertebral foramen, I have had little need to make book references. However, Santee's "Anatomy of the Brain and Spinal Cord," and Gray's "Anatomy," have both been consulted.

Zan D. Klopper, M. D., of Chicago, has drawn Plates 1 and 2 , and did the retouching of all the photomicrographs. I have sketched Plates 3 and 4 .

I desire to express my sincere thanks to my friend and former associate, L. D. Heigerick, for staining the original sections and for great aid rendered in the final proof-revision; to J. C. Vestergaard for much time spent in securing the photomicrographs; to Oakley Smith for encouragement early in the work; to Professor Harris E. Santee, M. D., for many valuable suggestions; and to my sister, Miss Marion G. Swanberg, and my wife for their valued assistance rendered in preparing and correcting the original manuscript.

Chicago, 1913.

HAROLD SWANBERG. 


\section{TABLE OF CONTENTS}

PAGE

Description of Plate 1 ............................... 20

Description of Plate 2 .................................. 24

Description of Plate 3 ................................ 28

Description of Plate 4 .............................. 32

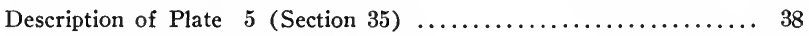

Description of Plate 6 (Section 33) ..................... 45

Description of Plate 7 (Section 31 ) ...................... 50

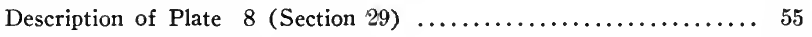

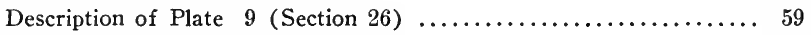

Description of Plate 10 (Section 24) ....................... 64

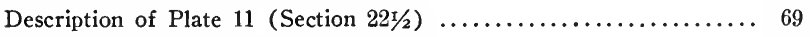

Description of Plate 12 (Section 21) ..................... 74

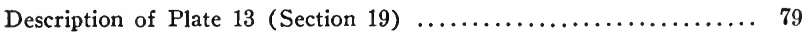

Description of Plate 14 (Section 17 ) .................... 83

Description of Plate 15 (Section 15) $\ldots \ldots \ldots \ldots \ldots \ldots \ldots \ldots \ldots \ldots . \ldots . \ldots . \ldots$

Description of Plate 16 (Section 13) $\ldots \ldots \ldots \ldots \ldots \ldots \ldots \ldots \ldots . \ldots . \ldots . \ldots . \ldots$

Summary $\ldots \ldots \ldots \ldots \ldots \ldots \ldots \ldots \ldots \ldots \ldots \ldots \ldots \ldots \ldots \ldots . \ldots \ldots$ 


\section{LIST OF PLATES}

PLATE

1. First and second dorsal vertebrae, with intervertebral disc connecting them, and vertebral extremity of right second rib (cat)

2. First and second dorsal vertebrae, with intervertebral disc connecting them, and vertebral extremity of right second rib

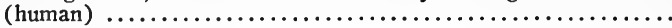

3. Right first dorsal intervertebral foramen and its adjacent bony

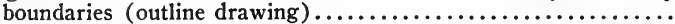

4. Second dorsal vertebra showing the spinal canal and its contents (partly diagrammatic)

5. Spinal canal and its adjacent bony boundaries opposite the right

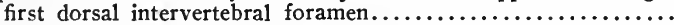

6. Spinal canal and its adjacent bony boundaries opposite the right first dorsal intervertebral foramen, external to Plate $5 . . . \ldots \ldots$.

7. Spinal canal and its adjacent bony boundaries opposite the right first dorsal intervertebral foramen, external to Plate $6 . . . \ldots$.

8. Spinal canal and its adjacent bony boundaries opposite the right first dorsal intervertebral foramen, external to Plate $7 . . . . .$. .

9. Right first dorsal intervertebral foramen and its adjacent bony

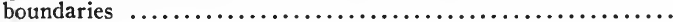

10. Immediately external to right first dorsal intervertebral foramen

11. External to right first dorsal intervertebral foramen, external

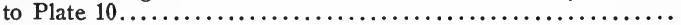

12. External to right first dorsal intervertebral foramen, external

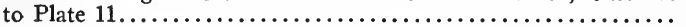

13. External to right first dorsal intervertebral foramen, external to Plate 12 .

14. External to right first dorsal intervertebral foramen, external

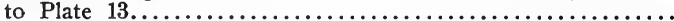

15. External to right first dorsal intervertebral foramen, external to Plate 14.

16. External to right first dorsal intervertebral foramen, external
to Plate $15 . \ldots \ldots \ldots \ldots \ldots \ldots \ldots \ldots \ldots \ldots \ldots \ldots \ldots \ldots \ldots \ldots \ldots \ldots \ldots \ldots \ldots \ldots \ldots \ldots \ldots$

16. External to right first dorsal intervertebral foramen, external
to Plate $15 \ldots \ldots \ldots \ldots \ldots \ldots \ldots \ldots \ldots \ldots \ldots \ldots \ldots \ldots \ldots \ldots \ldots \ldots \ldots \ldots \ldots \ldots \ldots \ldots$ 


\section{INTRODUCTION}

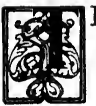

$\mathrm{HE}$ purpose of this book is to present an accurate and scientific description of an intervertebral foramen and its adjacent parts, with special reference to the relations of the nervous structures. The animal chosen to furnish the necessary specimen was the cat.*

ANIMAL. This was an ordinary eight-month-old female house cat which was pregnant when secured, one kitten being born on that day and another on the following day when she was etherized. A post-mortem was made, but no gross abnormal changes were noted. There was a slight normal congestion of the pelvic viscera present, due to the recent pregnancy. The cat measured about twenty inches from tip of nose to root of tail, this being the ordinary size. She was well built but not stout.

SPECIMEN. The right first dorsal intervertebral foramen was selected for study. The right half of the first and second dorsal vertebræ with the vertebral extremity (head and neck) of the right second rib attached was used as the specimen. The bones were sawed off, so that as small an amount of bone as possible was present around the intervertebral foramen. The specimen was placed, with the part where the spinal cord had been cut longitudinally, on a block and then

*'This animal and the human are very similar from a histologic and an anatomical standpoint, and they botb possess a cerebrospinal and sympathetic nervous system of similar arrangement. Specimens from this animal are even more desirable for study than the human because of their small size and of the ease with which fresh material can be obtained. The human specimens are too large to bave sections cut with the microtome suitable for microscopic examination, and, in addition, require too long 2 time for the bones to decalcify, which must be done in order to cut them. Each day the specimens are in the decalcifying fluid (nitric acid), the soft tissues are destroyed to a certain extent. 
mounted in this position. The sections were cut parallel to the sagittal plane. Such sections cut the spinal nerve transversely as it emerged from the intervertebral foramen and gave a complete view of the foramen. Sections, of course, were cut from without inward and labeled accordingly. Therefore, Section 1 would show structures completely external to the intervertebral foramen, while number 60 , the last one, would show structures inside the spinal canal, as the spinal cord. Sixty sections in all were prepared, each being about 14 microns ( $1 / 1800$ of an inch) in thickness and from 70 to 140 microns apart. However, all the sections are not shown in this text because there would not be enough change between each. Photomicrographs and descriptions for every alternate one from numbers 13 to 35 , are given, there being twelve of them in all.

It is extremely important that the reader should understand just how the specimen was cut if he wishes to interpret the photomicrographs.

DESCRIPTION OF PLATES. Plates 1 to 4 show drawings which will help the reader to better understand the photomicrographs which follow.

Plates 5 to 16 , the remaining ones, are retouched photomicrographs of the intervertebral foramen and its adjacent parts. Each plate corresponds to a section and the plates are enumerated from within outward, that is, reversing the order in which they were cut. Plate 5, the first photomicrograph, represents a section inside the spinal canal, and Plate 16 , the last one, represents a section outside of the intervertebral foramen. Since the photomicrographs correspond to every alternate section they are from 140 to 280 microns apart (1/180 to $1 / 90$ of an inch).

Arrangement of Photomicrographs. Plates 5, 6, 7 and 8 (Sections 35, 33, 31, 29) are taken internal to the intervertebral foramen, viz., in the spinal (vertebral) canal. 
Plate 9 (Section 26) is in the intervertebral foramen proper.

Plates 10, 11, 12, 13, 14, 15 and 16 (Sections 24, 221/2, 21, $19,17,15,13)$ are external to the intervertebral foramen.

Plates 8 and 10 are so close to the intervertebral foramen that they could almost be considered as in it.

TECHNIQUE. The specimen was carefully dissected, all possible traumatism being avoided. It was put through the usual histologic technique, using Orth's fluid for a fixing agent, nitric acid for decalcification, alcohol for hardening and celloidin for mounting. The sections were stained with (Delafield's) hematoxylin and eosin.

MEASUREMENTS. The metric system is used in all the work. A micron $(\mu)$ is equivalent to $1 / 1000$ of 1 millimeter, (mm.), or about $1 / 25000$ of an inch. One $\mathrm{mm}$. is equivalent to about $1 / 25$ of an inch.

THE SPINAL NERVE. The spinal nerve is formed by the anterior or efferent (motor) and posterior or afferent (sensory) roots which pass from the spinal cord.

Anterior (Motor) Root. The emergence is by several filaments from the antero-lateral groove of the spinal cord; the real origin being in the anterior horns of the cord.

Posterior (Sensory) Root. The emergence is by several filaments from the postero-lateral groove of the spinal cord; the real origin being in the ganglion on the posterior root. It is larger in size than the anterior root on account of there being more sensory than motor nerves in the body. It is further distinguished from the anterior root by the presence of a ganglion on it, called the spinal ganglion. The spinal ganglion is situated on the posterior root just before it unites with the anterior root in the spinal canal and is located opposite to the intervertebral foramen. (See Plates 4, 5,6 and $\%$.)

The anterior and posterior roots unite in the spinal canal 
or at the junction of the spinal canal and intervertebral foramen to form the spinal nerve. The nerve passes through the intervertebral foramen, and after emerging from it completely, bifurcates into an anterior and a posterior primary division. The anterior primary division is by far the larger, for it is the one which helps form the various plexuses to supply the muscles and skin of the arm, leg, etc. The posterior primary division is smaller for it supplies only a few spinal muscles and a little skin over the spine. The spinal nerve contains sensory and motor fibers and gives off both fibers to its anterior and posterior divisions. There are, however, a few exceptions to this arrangement.

SYMPATHETICS. Like the spinal nerves, the sympathetics consist of two kinds of fibers-efferent (vasomotor, secretory, etc.) and afferent (sensory). The efferent fibers arise in the lateral horn of gray matter in the spinal cord, pass out in the anterior root and then into the spinal nerve. Here they unite with the afferent fibers which take origin from the spinal ganglion on the posterior root of the spinal nerve. The efferent and afferent fibers then pass together into the anterior primary division of the spinal nerve. Leaving this, they form the white rami communicantes, and pass to the ganglion of the sympathetic cord in this situation. Sympathetic fibers also pass from the ganglion of the sympathetic cord back to the spinal nerve. These are called gray rami communicantes. They accompany the white rami and join the anterior primary division. Gray rami pass to every spinal nerve and accompany its various divisions. Every cranial nerve also has a sympathetic connection, but those fibers which pass to them are not called gray rami, yet they are similar to them. White rami, however, are only derived from the first dorsal to second lumbar nerves (inclusive), and from the second, third, and fourth sacral nerves. The sympathetic 
fibers that pass through the intervertebral foramen are in the substance of the spinal nerve.

The photomicrographs in this text show the following nervous structures:

1. Anterior and posterior roots; spinal ganglion on posterior root;

2. Spinal nerve;

3. Anterior and posterior primary divisions;

4. White and gray rami communicantes of the sympathetic.

Sympathetic fibers are, no doubt, present in the spinal nerve and its divisions as shown in these plates, but they cannot be distinguished from the other nerve fibers. However, white rami leaving and gray rami entering the anterior primary division of the spinal nerve are shown. (See Plate 15.) They accompany one another and are very closely associated, being separated by only a very small amount of fibrous tissue.*

*These findings agree with those of Langley, who writes in Schäfer's Physiology, "The uppermost thoracic white and grey rami are too closely associated to be cut separately." 


\section{DESCRIPTION OF PLATE 1}

This plate shows the first and second dorsal vertebrae, with the intervertebral disc connecting them, and the vertebral extremity of the right second rib of the cat. It is enlarged three diameters, therefore is about the same size as the human vertebrae. The first dorsal intervertebral foramen is located between the first and second dorsal vertebrae. The boundaries of the foramen are shown and labeled in descriptive terms of human anatomy.

The Boundaries of Right First Dorsal Intervertebral Foramen

Anterior $\left\{\begin{array}{l}\text { Body of first dorsal (above). } \\ \text { Head of second rib (below body). } \\ \text { (The external lateral part of the intervertebral disc } \\ \text { also forms an anterior boundary, but this is not } \\ \text { shown here, it being internal to the head of the } \\ \text { rib.) }\end{array}\right.$ Posterior $\left\{\begin{array}{l}\text { Inferior articular process of first dorsal (above). } \\ \text { Superior articular process of second dorsal (below). }\end{array}\right.$

Superior $\{$ Pedicle of first dorsal.

Inferior $\{$ Pedicle of second dorsal.

The boundaries of this intervertebral foramen are the same as in the human spine. Only the head and neck of the rib are shown here, the remaining part having been sawed off. The head of the rib is the only part of that bone which helps to form the anterior boundary of the foramen, the neck being too far external. 


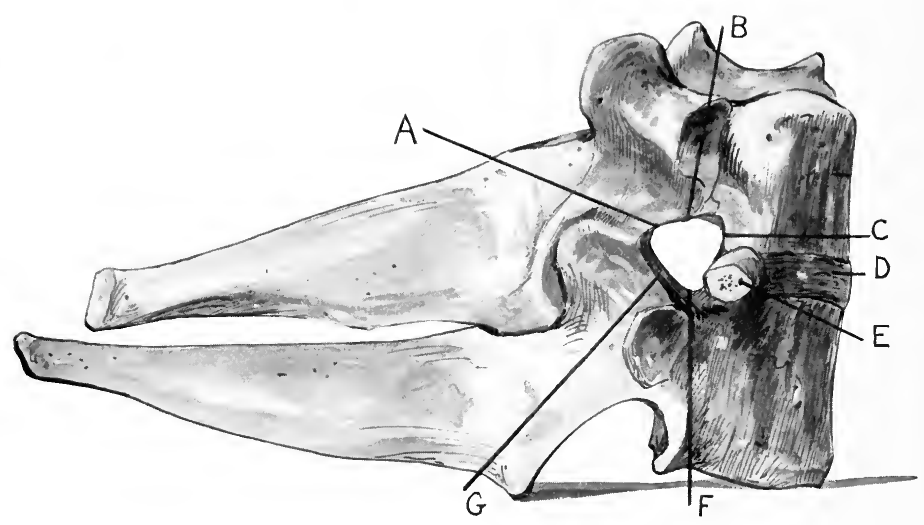

A right lateral view of the first and second dorsal vertebrae, with the intervertebral disc connecting them, and the vertebral extremity (head and neck) of the right second rib of the cat. (3 diameters.)

A-Inferior articular process of first dorsal.

B-Pedicle of first dorsal.

C-Body of first dorsal.

D-Intervertebral disc.
E-Head and neck of second rib.

F-Pedicle of second dorsal.

( - Superior articular process of second dorsal. 
The first and second dorsal vertebrae of the cat almost correspond with the same vertebrae in the human, having the same general shape and arrangement. They differ, however, in the cat as follows: (1) The spinous processes are much longer. (2) The transverse processes are in front of the articular processes. (3) The superior articular processes face backward and inward. (4) The inferior articular processes of the first dorsal faces forward and outward.

The same anatomical directions are used here and throughout the text as in the human, although they should be different. For example: In the human spine, the bodies of the vertebrae are anterior to the spinous processes, but the cat, being a quadruped, the bodies of the vertebrae are inferior to the spinous processes. However, it was thought best to use the same anatomical directions as in the human so as to avoid confusion. 


\section{DESCRIPTION OF PLATE 2}

This shows the first and second dorsal vertebrae with the intervertebral disc connecting them and the vertebral extremity of the right second rib in the human. It is life size and is shown in the same position and view as Plate 1 . It gives an excellent idea of how similar these bones are with those in the cat, the intervertebral foramen of both (right first dorsal) having the same boundaries. (See Plate 1.) 


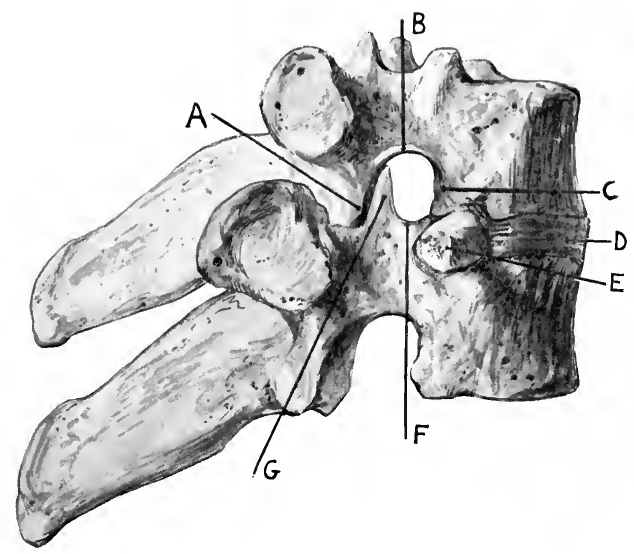

A right lateral view of the first and second dorsal vertebrae, with the intervertebral disc connecting them, and the vertebral extremity (head and neck) of the right second rib, of the human. (Life size.)

A-Inferior articular process of first dorsal.

B-Pedicel of first dorsal.

C-Body of first dorsal.

D-Intervertebral disc.
E-Head and neck of second rib.

F-Pedicle of second dorsal.

$\mathrm{G}$-Superior articular process of second dorsal. 



\section{DESCRIPTION OF PLATE 3}

This plate is an outline drawing of Plate 9 and shows the right first dorsal intervertebral foramen and its adjacent bony boundaries. It is enlarged 13 diameters, therefore, is about four times the size of the human. The foramen is somewhat quadrilateral in shape, has the same bony boundaries, and is shown in the same position as Plates 1 and 2. The foramen measures approximately $4 \mathrm{~mm}$. (1/6 of an inch) in its greatest antero-posterior and supero-inferior diameters. The darkened areas represent the hyaline articular cartilage.

\section{The Articular Cartilage on Bony Boundaries}

1. The inferior articular process of the first dorsal.

2. The superior articular process of the second dorsal.

3. The body of the first dorsal.

4. The body of the second dorsal.

5. The head of the second rib.

The cartilage is placed on the articular processes, where they articulate with one another, and on the bodies of the vertebrae and head of rib where they articulate. It averages about 230 microns ( $1 / 110$ of an inch) in thickness on the articular processes. The first dorsal spinal nerve is shown in the center of the foramen. It measures 2.95 by $1.4 \mathrm{~mm}$. $(1 / 8 \times 1 / 18$ of an inch), is oval in shape, and is situated obliquely in the middle of the foramen. It occupies about onethird of the total area of the foramen and is not in contact with bone at any place. It is closest to bone at its anterosuperior part, where it is 300 microns (1/80 of an inch) from 


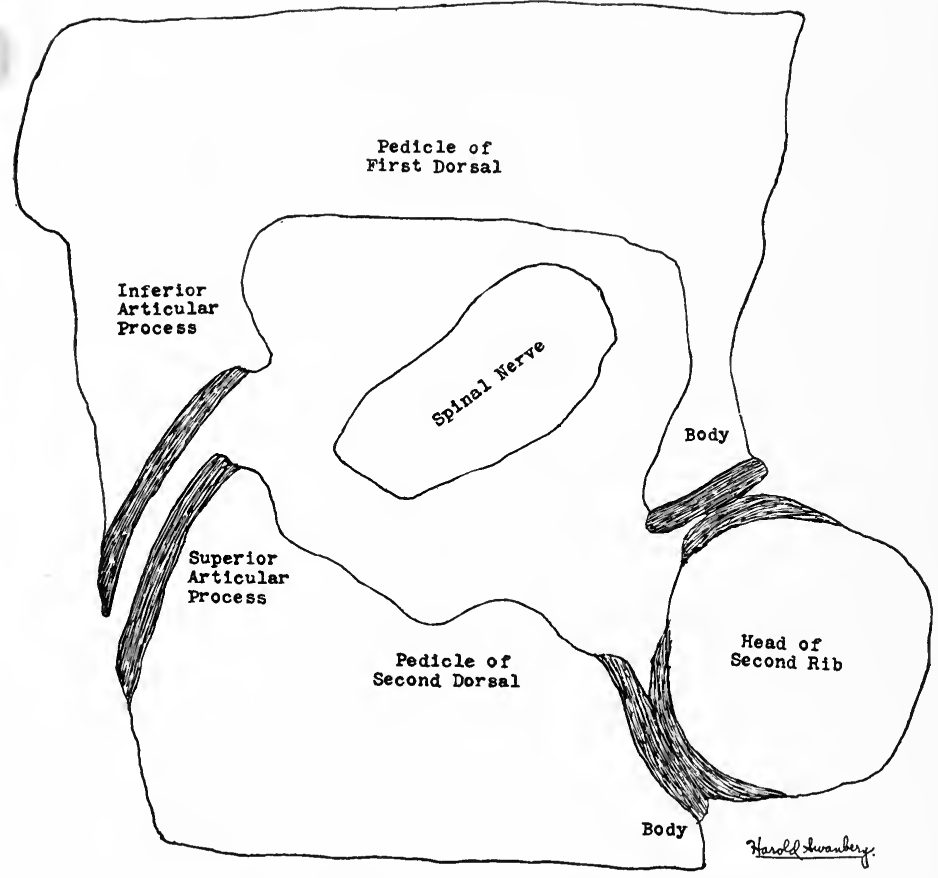

A right lateral view of the right first dorsal intervertebral foramen, with its adjacent bony boundaries, and the position and size of the right first dorsal spinal nerve. (Drawn from Plate 9-13 diameters.) 
the pedicle of the first dorsal. The long diameter of the nerve runs from the antero-superior to the postero-inferior part of the foramen. The other structures in the foramen, fat cells, fibrous tissue, and blood vessels, are shown in the photomicrographic plates. 


\section{DESCRIPTION OF PLATE 4}

This shows the second dorsal vertebra with its spinal canal and contents. It is diagrammatic and is enlarged six diameters so is about twice the size of the human. The sizes of the vertebra, spinal canal, and spinal cord are correct proportionally. The spinal membranes, the spinal nerve and its divisions are shown diagrammatically. The plate is shown as if one were looking down upon the cord at this level, and the first dorsal spinal nerve is seen passing above the pedicle of the second dorsal vertebra.

\section{The Boundaries of Spinal Canal (at This Level)}

Anterior $\left\{\begin{array}{c}\text { Body of second dorsal-(the posterior longitudinal } \\ \text { ligament is attached to its posterior surface). }\end{array}\right.$

Lateral $\{$ Pedicle of second dorsal.

Posterior $\left\{\begin{array}{l}\text { Articular processes of second dorsal, laterally. } \\ \text { Laminae of second dorsal, medially (the ligamen- } \\ \text { tum flava is attached to their anterior surface). }\end{array}\right.$

The above boundaries are the same as in the human. The canal is almost circular in shape, and the spinal cord which has nearly the same shape, is situated in the center, occupying half the space. The size of the canal at this level is $8 \times 6 \mathrm{x} / 2$ $\mathrm{mm}$. and the cord about $4 \times 3 \mathrm{r} / 4 \mathrm{~mm}$.

The cord is surrounded by the pia mater, a thin membrane, which is intimately adhered to it, and which dips down into the anterior median fissure of the cord.

External to the pia, the arachnoid is present; it is the thinnest of the cord membranes and is held in contact to the pia by trabeculae of delicate connective tissue fibers called the subarachnoid reticulum. In the recent state, this reticu- 


\section{PLATE 4}

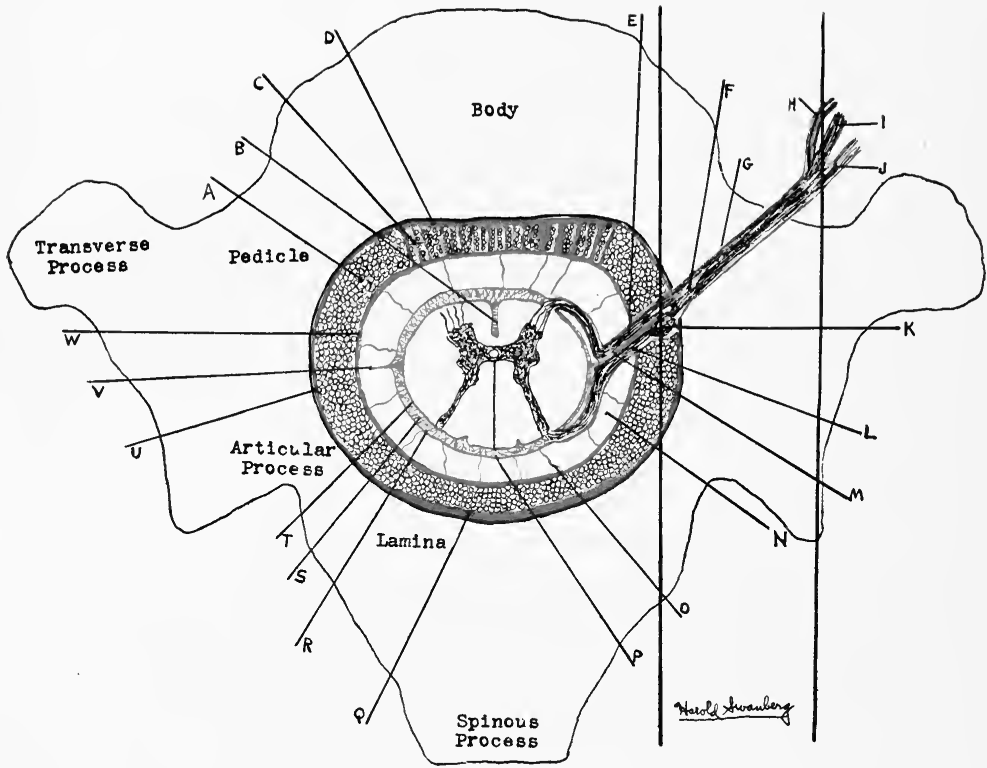

A transverse section of the second dorsal vertebra showing the spinal (vertebral) canal and its contents. Partly diagrammatic. (6 diameters.)

A-Epidural space filled with fat cells. $\mathrm{B}$-Anterior median fissure of spinal cord.

$\mathrm{C}$-Fibrous tissue connecting dura and post. long. ligament.

D-Posterior longitudinal ligament.

$\mathrm{E}$-Anterior root of spinal nerve.

$\mathrm{F}$-Spinal nerve.

G-Epineurium.

$\mathrm{H}$-White and gray rami of the sympathetic.

I-Anterior primary division of spinal nerve.

$\mathrm{J}$-Posterior primary divisions of spinal nerve.

$\mathrm{K}$-Spinal ganglion.

L-Posterior root.
M-Fibrous tissue uniting the two roots.

$\mathrm{N}$-Subdural space.

$\mathrm{O}$-Fibrous tissue fibers connecting dura with arachnoid.

P-Septum posticum.

O-Ligamentum flava.

R-Arachnoid.

S-Subarachnoid space containing arachnoid reticulum.

$\mathrm{T}$-Pia mater.

U-Periosteum lining spinal canal.

$\mathrm{V}$-Ligamentum denticulatum.

W-Dura mater.

All the fibrous tissue is shown in red. The two vertical lines indicate the extent of sections shown in the photomicrographic plates which follow. 

lum is distended and the space between the arachnoid and pia is spoken of as the subarachnoid space. It contains a considerable amount of cerebro-spinal fluid and a number of blood vessels. Opposite the posterior median groove, the subarachnoid space is practically subdivided by a longitudinal, membranous, fenestrated partition called the septum posticum which connects the arachnoid with the pia. The arachnoid is really the external layer of the pia. The two membranes can be separated only with difficulty, and could therefore be considered as one, the pia-arachnoid.

External to the arachnoid we find the dura mater. This is the thickest of the membranes. It is separated from the arachnoid by a clear space called the subdural space. This space contains a few trabeculae of connective tissue which connect it to the arachnoid here and there, and just enough cerebrospinal fluid to moisten the surface. Outside of the dura, and between it and the bony margin of the spinal canal, we find a very large space called the epidural space. It contains mostly fat, together with blood vessels and some fibrous connective tissue fibers. These last are seen in the anterior part, helping to support the dura and running from this membrane to the posterior longitudinal ligament.

In the above description, nothing has been mentioned of the ligamentum denticulata. These are folds of pia which extend from the lateral part of the cord to the inner side of the lateral part of the dura mater, in the interval between the spinal nerves, and push the arachnoid before them. At the level of the spinal nerves they do not reach the dura but are free (as in this plate). They divide the subarachnoid and subdural spaces into two parts, and separate the anterior and posterior roots of the spinal nerve from one another. They also help to support the cord.

The anterior and posterior nerve roots pass horizontally lateral from their respective emergences at the antero- 
lateral and postero-lateral grooves, to the mid-lateral side of the cord. They are invested in their course by the pia mater which is really continuous on them from the cord. The arachnoid also invests the roots but only as far as where they pierce the dura mater. The two roots at the mid-lateral part of the cord pierce the dura separately, and this membrane passes onto and covers them. However, the dura which covers the roots is by no means as thick as that which invests the cord. Both the pia and dura continue out on the roots, the spinal nerve and its divisions, and form the epineurium of all the peripheral nerves.

After the two roots pierce the dura separately, they are held closely together by fatty-fibrous tissue. They then pass through the epidural space and are entirely surrounded by fat. The posterior root, just before it unites with the anterior root, and, while it is in the spinal canal immediately internal to the intervertebral foramen, has an enlargement developed on it - the spinal ganglion. Immediately after leaving the ganglion, the two roots coalesce, forming the spinal nerve. This passes through the intervertebral foramen, and after emerging from it completely, bifurcates into a large anterior and several small posterior primary divisions. From the anterior primary division the white rami of the sympathetic leave and the gray rami enter. The fat that is present in the epidural space passes into the intervertebral foramen and almost entirely surrounds the nerve in this situation.

The space between the two vertically drawn lines in the plate shows the extent of structures as shown in the photomicrographic plates which follow. The vertical line, inside the spinal canal, cutting the anterior and posterior roots corresponds to Plate 5 (Section 35). The vertical line, outside of the intervertebral foramen, cutting the anterior and posterior primary divisions, and the white and gray rami of the sympathetic corresponds to Plate 16 (Section 13). 


\section{SUMMARY OF SPACES AND MEMBRANES \\ IN SPINAL CANAL}

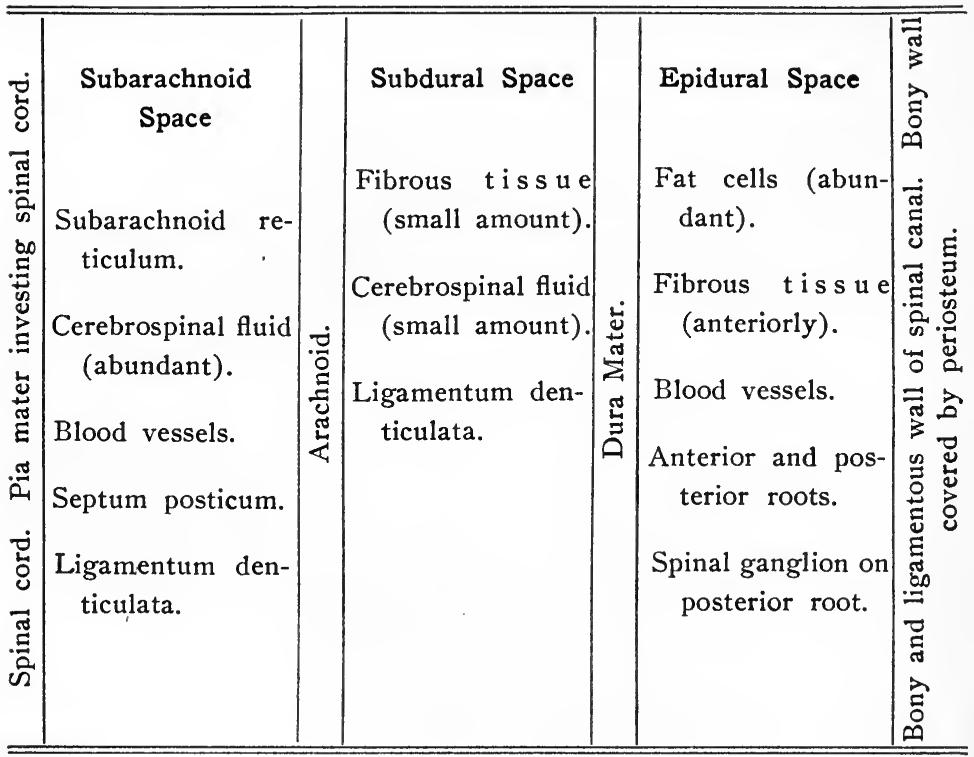




\section{DESCRIPTION OF PLATE 5 (SECTION 35)}

This, and all of the following plates are photomicrographs of the right first dorsal intervertebral foramen and its adjacent parts. Each is seen in a right lateral view, and is enlarged approximately 13 diameters.

This is the most internal plate of the series and shows the spinal canal and its adjacent bony boundaries opposite the right first dorsal intervertebral foramen. It is really in the epidural space, that is, the space between the dura mater and the bony walls of the spinal canal. It is cut in the same manner as Plate 3, except that it is internal to this plate. However, the same general directions that were given in connection with the above will apply to this plate. The anterior, posterior, superior and inferior directions are labeled on the plate as well as the bony boundaries. On passing internal from here far enough, the spinal cord is encountered and passing external a short distance, the intervertebral foramen is entered.

The Bony Boundaries of Spinal Canal (as Shown in This Plate)

Anterior $\left\{\begin{array}{l}\text { Body of first dorsal (above). } \\ \text { Head of second rib (middle). } \\ \text { Body of second dorsal (below). }\end{array}\right.$

$\left\{\begin{array}{l}\text { Inferior articular process of the first dorsal } \\ \text { (above). } \\ \text { Superior articular process of the second dorsal }\end{array}\right.$

Posterior $\left\{\begin{array}{l}\text { Superior articular process of the second dorsal } \\ \text { (below). }\end{array}\right.$ (These are held together by part of the capsular ligament which can be seen in the canal.)

Part of the interarticular ligament of the costo-central articulation is seen attached to the posterior surface of the 


\section{(Superior)}

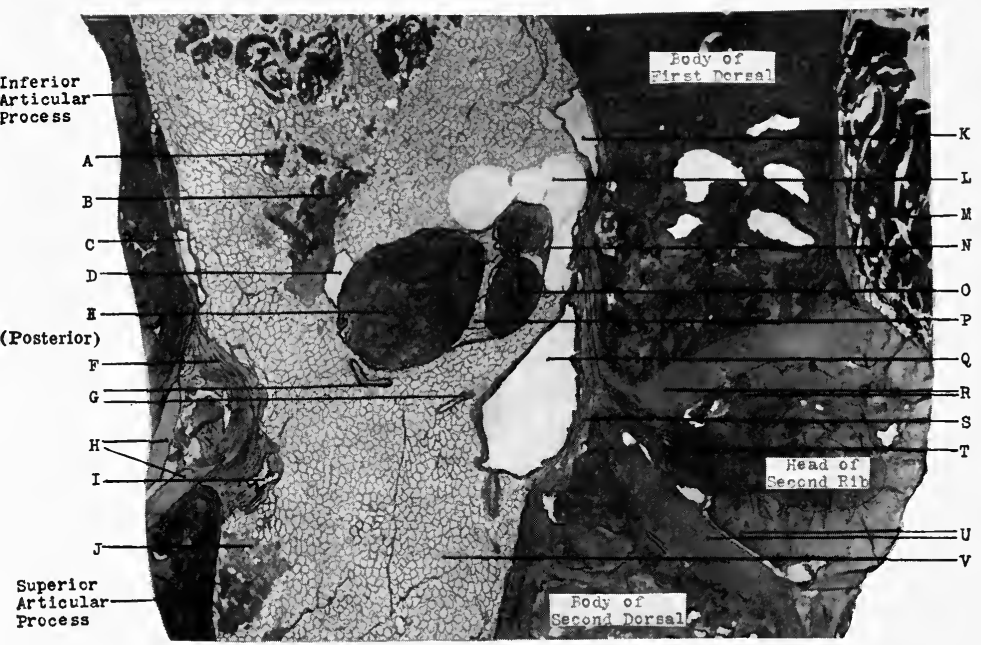

(Inferior)

A right lateral view of the spinal canal and its adjacent bony boundaries opposite the right first dorsal intervertebral foramen.

A-Foreign particles.

B-Unknown particle.

C-Blood vessel.

D-Vacant space.

E-Posterior root of spinal nerve (spinal ganglion).

$\mathrm{F}$-Capsular ligament.

$\mathrm{G}$-Blood vessels.

$\mathrm{H}$-Articular cartilages.

I-Blood vessel.

J-Foreign particles.
K-Blood vessel.

L-Vacant space.

M-Voluntary muscle.

$\mathrm{N}-$ Blood vessel.

$\mathrm{O}$-Filaments of anterior root of spinal nerve.

P-Fatty-fibrous tissue.

Q-Blood vessel (greatly distended).

$\mathrm{R}$-Articular cartilages.

S-Fibrous tissue (dense).

$\mathrm{T}$-Interarticular ligament.

U-Articular cartilages.

V-Fat cells.

(Anterior) 

head of the rib. The most internal part of each articular process is the part present.

The reason that no bony boundaries are shown superiorly or inferiorly is because this section is in the spinal canal. Passing externally a short distance and entering the intervertebral foramen, the pedicle of the first dorsal is found above and the pedicle of the second dorsal below. All the bone present, in this and the following plates, is of a cancellous nature, covered with an outer layer of compact bone which is typical of the vertebrae and ribs.

\section{The Articular Cartilage on Bony Boundaries.}

1. Inferior articular process of first dorsal.

2. Superior articular process of second dorsal.

3. Body of first dorsal.

4. Body of second dorsal.

5. Head of second rib.

Hyaline cartilage is seen on the above parts where the bones articulate. (In this plate there is a very small amount on the articular processes, but considerable on the bodies of the vertebrae and head of rib.)

Centering all efforts on the spinal canal itself, i. e., the space between the bony boundaries, the structures outside of the canal will not be considered.

\section{The Contents of Spinal Canal (as Shown in This Plate)}
1. Nervous Structures.
5. Vacant Spaces.
2. Fat Cells.
6. Foreign Particles
3. Blood Vessels.
7. Unknown Particle.
4. Fibrous Tissue. 


\section{Nervous Structures.}

Anterior and posterior roots (spinal ganglion on posterior root).

The two large structures in about the center of the canal are the anterior and posterior nerve roots. They are posterior to the lower part of the body of the first dorsal and are cut transversely. They are connected by fatty-fibrous tissue and are situated freely in the canal, being intimately surrounded by fat cells and vacant spaces. The roots have these same relations in the plates which follow. The anterior root consists of two separate filaments, each being surrounded by fibrous tissue. There are no nerve cells in either of the filaments. A small blood vessel is seen in the fibrous tissue separating them. The posterior root consists of a single filament, is larger, and is made up entirely of the posterior root ganglion (spinal ganglion) in this plate, for under high power magnification it shows numerous nerve cells. The ganglion is surrounded by fibrous tissue. The fibrous tissue which surrounds the nerves is derived from the dura and pia of the cord and is known as the epineurium.

\section{Fat Cells.}

The canal is almost entirely filled with them.

They form the main composition of the canal. They are all typical in structure and the nervous structures are embedded in them. Running throughout the fat, very fine strands of fibrous tissue are found here and there. Passing externally the fat cells gradually become less in number.

\section{Blood Vessels}

(1) Large distended one posterior to head of rib (largest).

(2) A small one in capsular ligament (distended).

(3) One of fair size posterior to body of first dorsal (distended). 
(4) One of fair size anterior to inferior articular process of first dorsal (distended).

(5) Two small ones in fat tissue inferior to nervous structures (collapsed).

(6) A very small one between the two filaments of anterior root.

The vessels are very numerous. The dark substance seen occasionally in their lumen throughout the plates is blood. No attempt has been made to distinguish the arteries from the veins.

\section{Fibrous Tissue.}

(1) Forming the epineurium of nervous structures.

(2) Forming the walls of blood vessels.

(3) Very fine fibers among the fat cells.

(4) Forming the periosteum of all the bones.

(5) Forming the internal part of the capsular ligament connecting the articular processes (dense).

(6) A small amount posterior to head of rib (dense).

(7) Uniting the anterior and posterior roots (fine).

The fibrous tissue is not very abundant in amount. The first four of the above occur throughout the plates, so will not be repeated. Passing externally the fibrous tissue steadily increases in amount.

\section{Vacant Spaces.}

(1) Anterior and superior to anterior root.

(2) Posterior to posterior root.

These are spaces where all tissue is absent. They are sometimes difficult to distinguish from blood vessels. However, in the case of a blood vessel the walls are thick and have the structure of a vessel. These spaces are, no doubt, due to faulty technic, for there are normally no vacant spaces in the tissues. They, no doubt, represent areas where the fat 
cells have been washed out. They appear at various situations in the plates which follow.

\section{Foreign Particles.}

(1) In the superior part of canal.

(2) In the inferior part of canal.

These consist mainly of irregularly scattered splinters of bone, due to the sawing that was necessary to secure the specimen.

7. Unknown Particle.

Posterior and superior to posterior root.

It evidently belongs to the nervous structure, for it becomes continuous with them internally. 


\section{DESCRIPTION OF PLATE 6 (Section 33)}

This shows the spinal canal and its adjacent bony boundaries external to Plate 5 .

\section{The Bony Boundaries of Spinal Canal \\ Similar to the former plate (Plate 5)}

Inferiorly, the pedicle of the second dorsal is beginning to form and this nearly fills the canal there. The head of the rib is more bony in composition. In the former plate it was mostly cartilaginous, which was due, no doubt, to the presence of the extreme internal part of the head of the rib. This part is covered with hyaline cartilage and articulates with the intervertebral disc. Naturally, passing externally, the cartilage gradually disappears, and bone takes its place. More of the articular processes can be seen in this plate, because of the fact that their most internal parts were shown in the former plate. The body of the first dorsal is smaller anteroposteriorly. This is due to the lateral sides of the vertebrae eventually terminating in a ridge. The canal is not so wide superiorly. The same reason which explained the change in the inferior part will also apply here. The spinal canal is oval in shape like the bodies of the vertebrae when cut transversely. As the canal passes laterally it becomes smaller in an antero-posterior direction, therefore it appears smaller in this plate than in the former. The interarticular ligament is smaller.

To sum up these bony changes:

1. The pedicle of second dorsal is beginning to form.

2. The inferior part of canal is smaller in an anteroposterior diameter. 
3. The head of rib is more bony in its composition.

4. The articular processes are larger.

5. The body of first dorsal is smaller in an antero-posterior diameter.

6. The superior part of canal is smaller in an anteroposterior diameter.

\section{The Articular Cartilage on Bony Boundaries}

Similar to the former plate (Plate 5)

\section{The Contents of Spinal Canal}

Similar to the former plate (Plate 5)

\section{Nervous Structures.}

Anterior and posterior roots (spinal ganglion on posterior root).

These roots are situated in about the same position, but appear closer together, less fatty-fibrous tissue separating them. The epineurium, surrounding the superior filament of the anterior root, appears slightly torn, due, no doubt, to faulty technic.

2. Fat Cells.

The canal is almost entirely filled with them.

They are less in number on account of the smaller size of the canal.

3. Blood Vessels.

(1) Large distended one posterior to head of rib (largest).

(2) One of fair size in capsular ligament (distended).

(3) One of fair size posterior to body of first dorsal (distended).

(4) A small one anterior to inferior articular process of first dorsal and capsular ligament (collapsed). 


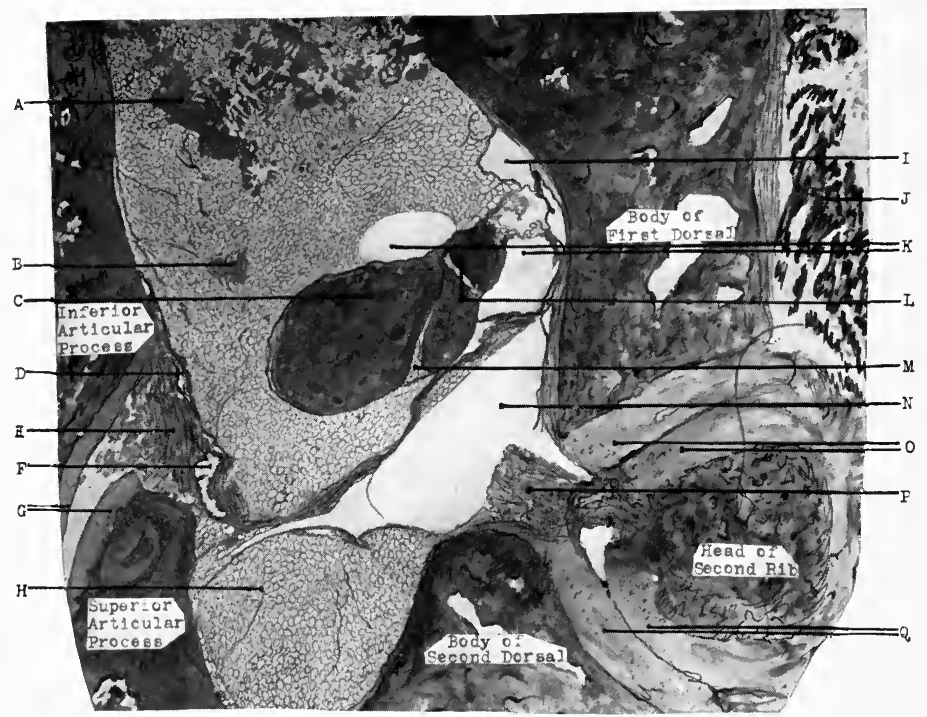

A right lateral view of the spinal canal and its adjacent bony boundaries opposite the right first dorsal intervertebral foramen, immediately external to Plate 5.

A-Foreign particles.

$\mathrm{B}$-Unknown particle.

C-Posterior root of spinal nerve (spiral ganglion).

I-Blood vessel.

D-Blood vessel.

J-Voluntary muscle.

K-Vacant spaces.

E-Capsular ligament.

$\mathrm{F}$-Blood vessel.

G-Articular cartilages,

H-Fat cells.

L-Filaments of anterior root of spinal nerve.

M-Fatty-fibrous tissue.

$\mathrm{N}$-Blood vessel (greatly distended).

O-Articular cartilages.

P-Fibrous tissue (dense).

Q-Articular cartilages. 
. 
The large vessel is seen as it passes posteriorly in the canal toward the capsular ligament. This vessel is larger than normal on account of it having folded at its superior part, due to faulty technic. Some fat cells can be seen in its lumen in this area. The vessel which was in the anterior root and those in the fat tissue inferior to the nervous structures have disappeared. They, no doubt, became continuous with the large vessel. The vessel anterior to the inferior articular process in the former plate, has descended somewhat and now lies partly anterior to that part and partly anterior to the capsular ligament. It may become continuous with the vessel in the ligament, for it appears smaller than in the former plate.

\section{Fibrous Tissue.}

(1) The capsular ligament (dense).

(2) Posterior to head of rib (dense).

(3) Uniting the anterior and posterior roots (fine).

Practically as in the former plate, but as a whole, slightly increased in amount. The capsular ligament is more prominent. The tissue posterior to the head of the rib more abundant.

\section{Vacant Spaces.}

(1) Anterior to anterior root.

(2) Superior to posterior root.

\section{Foreign Particles.}

In the superior part of canal.

They are becoming less in number and have entirely disappeared in the inferior part.

\section{Unknown Particle.}

Posterior and superior to posterior root.

It has almost entirely disappeared. This and the former plate are the only ones in which it is seen. 


\section{DESCRIPTION OF PLATE 7 (Section 31)}

This shows the spinal canal and its adjacent bony boundaries external to Plate 6 .

\section{The Bony Boundaries of Spinal Canal}

Anterior $\left\{\begin{array}{l}\text { Body of first dorsal (above). } \\ \text { Head of second rib (below). }\end{array}\right.$

Posterior $\left\{\begin{array}{l}\text { Inferior articular process of first dorsal (above). } \\ \text { Superior articular process of second dorsal (be- } \\ \text { low). }\end{array}\right.$

Inferior \{Pedicle of second dorsal.

Inferiorly the canal is bounded by the pedicle of the second dorsal. Therefore the body of the second dorsal is no longer an anterior boundary. These are the only changes in the bony boundaries. We still consider this plate as in the spinal canal for it cannot be considered as in the intervertebral foramen until it is entirely surrounded by bone.

We note the following bony changes:

1. The pedicle of second dorsal appears.

2. The superior part of canal is smaller in diameter.

3. The body of first dorsal is smaller in an antero-posterior diameter.

4. The articular processes are larger.

In other words there is a continuation of practically all the changes that were spoken of in the foramen plate. The interarticular ligament is practically the same as in the former plate. 


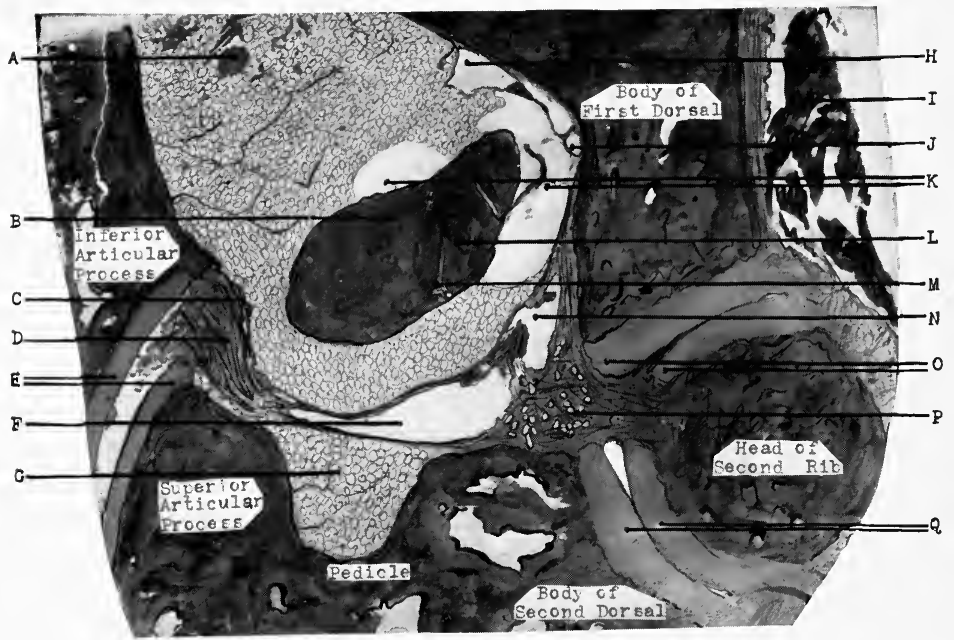

A right lateral view of the spinal canal and its adjacent bony boundaries, opposite the right first dorsal intervertebral foramen, immediately external to Plate 6 .

A-Foreign particles.

B-Posterior root of spinal nerve (spinal ganglion).

C-Blood vessel.

D-Capsular ligament.

E-Articular cartilages.

F-Blood yessel.

G-Fat cells.

H-Blood vessel.

I-Voluntary muscle.

T-Blood vessel.

L-Vacant spaces. spinal nerve.

M-Fatty-fibrous tissue.

$\mathrm{N}$-Blood vessel.

O- - rticular cartilages.

P-Fatty-filorous tissue.

Q-Articular cartilages. 



\section{The Articular Cartilage on Bony Boundaries}

Similar to the former plates (See Plate 5)

\section{The Contents of Spinal Canal}
1. Nervous Structures.
4. Fibrous Tissue.
2. Fat Cells.
5. Vacant Spaces.
3. Blood Vessels.
6. Foreign Particle.

They are the same as in the former plates except that the unknown particle has disappeared.

\section{Nervous Structures.}

Anterior and posterior roots (spinal ganglion on posterior root).

The roots have almost fused. The inferior filament of the anterior root is more closely associated with the posterior root than the superior filament. A few nerve cells are still present in the posterior root and part of the epineurium of the anterior root appears very loose.

2. Fat Cells.

(1) The canal is nearly filled with them.

(2) In the fibrous tissue posterior to head of rib.

As a whole they are less in number. There are none in the fibrous tissue which separates the roots, but there are some infiltrating the fibrous tissues posterior to the head of the rib.

\section{Blood Vessels.}

(1) Two large ones inferior to nervous structures (distended).

(2) A small one in capsular ligament (collapsed). 
(3) Two posterior to body of first dorsal, one fair size, the other small (both distended).

The large distended vessel of the former plate has bifurcated into two vessels. The more posterior of these vessels apparently receives the vessel formerly seen in the capsular ligament for this has disappeared. The vessel which was situated anterior to the inferior articular process and capsular ligament has descended still further and is now entirely in the anterior part of the ligament. The vessel posterior to the body of the first dorsal has a very small vessel accompanying it, which, no doubt, is derived from it.

\section{Fibrous Tissue.}

(1) The capsular ligament (dense).

(2) Posterior to head of rib (infiltrated with fat).

(3) Uniting anterior and posterior roots.

The capsular ligament is still more prominent. The tissue posterior to the rib is thicker. Very little tissue unites the roots.

5. Vacant Spaces.

(1) Anterior to anterior root.

(2) Superior to posterior root.

6. Foreign Particles.

In the superior part of canal.

These are still further reduced in number. 


\section{DESCRIPTION OF PLATE 8 (Section 29)}

This shows the spinal canal and its adjacent bony boundaries external to Plate No. \%.

\section{The Bony Boundaries of Spinal Canal \\ Similar to the former plate (Plate 7 )}

The pedicle of the second dorsal has fully formed. The canal has been further reduced in size and the intervertebral foramen is almost formed, the deficiency being in the pedicle of the first dorsal above. In fact, this plate could be considered as in the intervertebral foramen.

The bony boundaries show the following changes as compared with the former plate:

1. The pedicle of second dorsal is larger.

2. The superior part of foramen is smaller.

3. The body of first dorsal is smaller in an antero-posterior diameter.

4. The articular processes are larger.

5. The pedicle of first dorsal is beginning to form.

\section{The Articular Cartilage on Bony Boundaries}

Similar to the former plates (see Plate 5)

The Contents of Spinal Canal

Similar to the former plate (Plate 7)

\section{Nervous Structures.}

The spinal nerve.

The roots have practically fused and the nerve has been formed. It is oval in shape, situated obliquely in the canal 
and surrounded by fat cells and vacant spaces. A little loose fibrous tissue is attached to the epineurium at its anterosuperior part. Nerve cells are present in its posterior part which is the situation where the spinal ganglion was formerly seen. Evidently, nerve cells are not confined solely to the ganglion.

\section{Fat Cells.}

(1) The canal is nearly filled with them.

(2) In the fibrous tissue posterior to the head of rib.

There are more in the fibrous tissue posterior to the head of rib than before, but, as a whole, they are fewer in number.

\section{Blood Vessels.}

(1) Two large ones inferior to nerve (distended).

(2) A small one in capsular ligament (collapsed).

(3) Two posterior to body of first dorsal, one fair size, the other small (both distended).

The vessels appear about the same except that the wall which separates the two large ones is thicker.

\section{Fibrous Tissue.}

(1) The capsular ligament (dense).

(2) Posterior to head of rib (infiltrated with fat).

(3) Attached to antero-superior part of nerve (fine).

It is increased in amount. Posterior to the head of the rib it is thicker. A little loose tissue is attached at the anterosuperior part of the nerve.

\section{Vacant Spaces.}

(1) Anterior to nerve.

(2) Superior to nerve.

6. Foreign Particles.

In the superior part of canal.

Only a very few particles remain. 


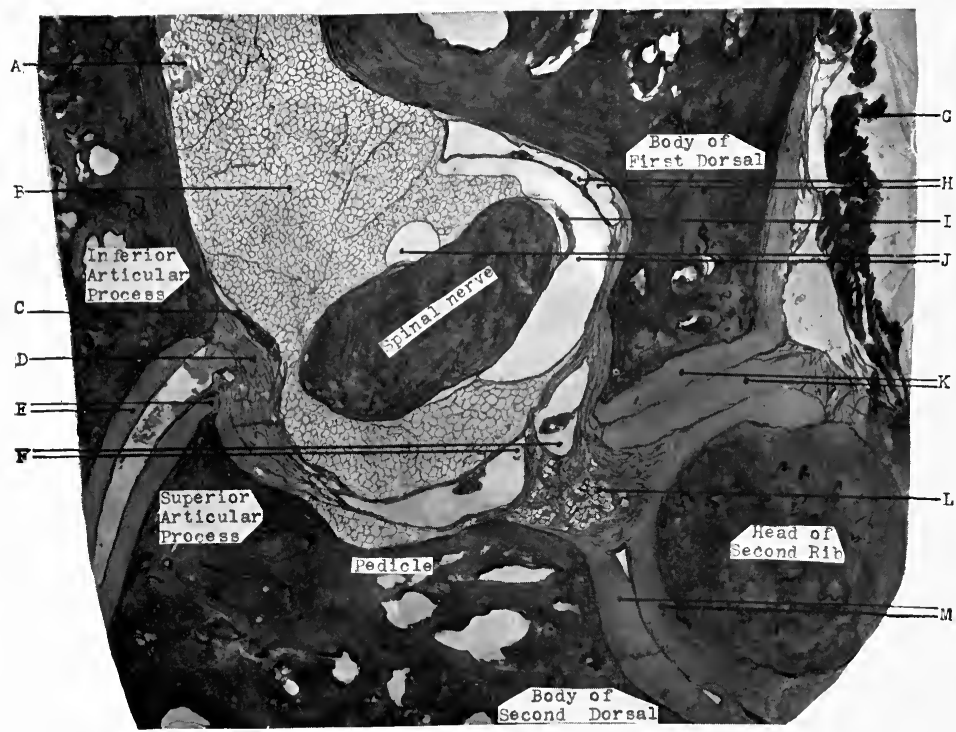

A right lateral view of the spinal canal and its adjacent bony boundaries, immediately internal to the right first dorsal intervertebral foramen and immediately external to Plate \%.*

A-Foreign particles.

B-Fat cells.

C-Blood vessel.

D-Capsular ligament.

E-Articular cartilages.

F-Blood vessels.
G-Voluntary muscle.

H-Blood vessels.

I-Fibrous tissue (fine)

J-Vacant spaces.

K-Articular cartilages.

L - Fatty-fibrous tissue.

M-Articular cartilages.

* This plate is so close to the intervertebral foramen that it could almost be considered as in the most internal part of the foramen. 


\section{19.9.811}

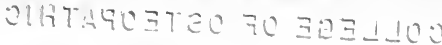

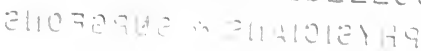




\section{DESCRIPTION OF PLATE 9 (Section 26)}

This shows the right first dorsal intervertebral foramen, and its adjacent bony boundaries.

The Bony Boundaries of Intervertebral Foramen

Anterior $\left\{\begin{array}{l}\text { Body of first dorsal (above). } \\ \text { Head of second rib (below). }\end{array}\right.$

Posterior $\left\{\begin{array}{l}\text { Inferior articular process of first dorsal (above). } \\ \text { Superior articular process of second dorsal (be- } \\ \text { low). }\end{array}\right.$

Superior $\{$ Pedicle of first dorsal.

Inferior \{Pedicle of second dorsal.

Being in the intervertebral foramen it is entirely surrounded by bone. Therefore, the pedicle of the first dorsal is seen in addition to the parts in the former plate. This plate has the same boundaries as given under Plate 3, which is a drawing from this. The body of the first dorsal is still further reduced in an antero-posterior diameter and appears quite thin.

\section{The Articular Cartilage on Bony Boundaries}

Similar to the former plates (see Plate 5)

These are well shown in Plate 3.

\section{The Contents of Intervertebral Foramen}

1. Nervous Structures.

4. Fibrous Tissue.

2. Fat Cells.

5. Vacant Spaces.

3. Blood Vessels.

They are similar to the former plate except that the foreign 
particles have entirely disappeared. The foramen is somewhat quadrilateral in shape.

\section{Nervous Structures.}

The spinal nerve.

Its general shape and size are shown very well in Plate 3. A brief description of it is also given in connection with the above plate. The nerve is surrounded by fat cells and vacant spaces. The capsular ligament is now in contact with it slightly postero-inferiorly and some loose fibrous tissue is seen attached antero-superiorly. Nerve cells remain present in its posterior part.

2. Fat Cells.

(1) Postero-superior to nerve.

(2) Inferior to nerve.

(3) In the fibrous tissue posterior to head of rib.

They are markedly reduced in number on account of being in the intervertebral foramen. Next to the nerve they occupy the most space. The fat cells in the fibrous tissue posterior to the head of the rib have further increased in number.

3. Blood Vessels.

(1) Four fair sized ones in fibrous tissue inferior to the nerve (all distended).

(2) A small one in capsular ligament (collapsed).

(3) Three of fair size inferior to pedicle of first dorsal (all distended).

The two large vessels seen in the former plate have further divided into four. They appear imbedded in fibrous tissue inferior to the nerve. The two vessels situated posterior to the body of the first dorsal in the former plate, are now three in number and are seen passing beneath the pedicle of the first dorsal. 


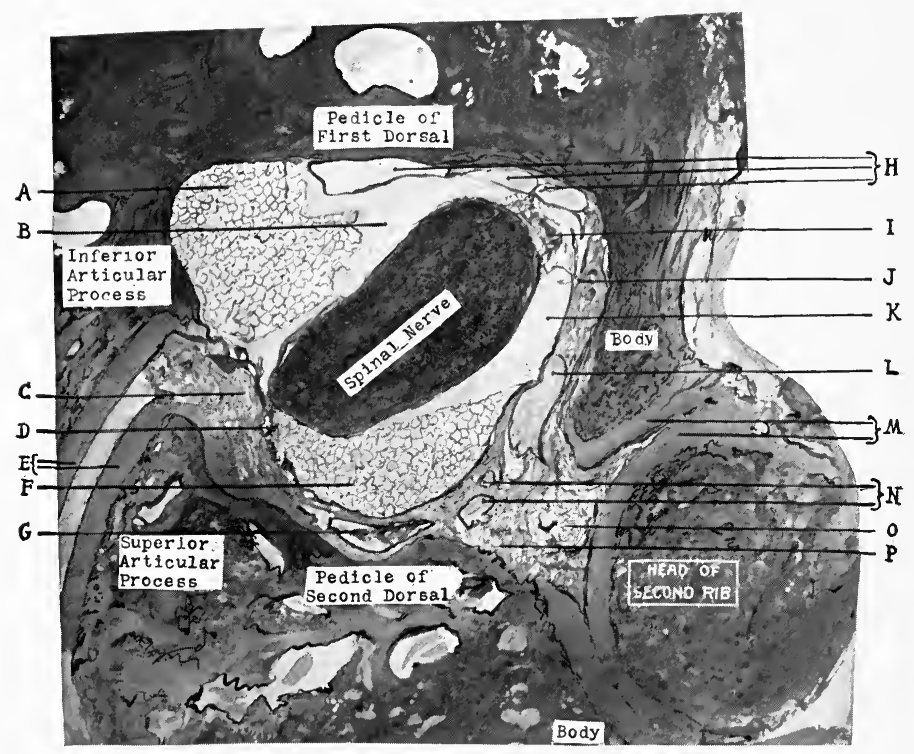

A right lateral view of the right first dorsal intervertebral foramen and its adjacent bony boundaries. It is, of course, external to Plate 8 , which was in the spinal canal.

A-Fat cells.

B-Vacant space.

C-Capsular ligament.

D-Blood vessel.

E-Articular cartilages.

F-Fat cells.

G-Blood vessel.
$\mathrm{H}-\mathrm{Blood}$ vessels.

I-Fibrous tissue (loosely arranged).

J-Thickened periosteum.

K-Vacant space.

I-Blood vessel.

M-Articular cartilages.

$\mathrm{N}$-Blood vessels.

O-Fatty-fibrous tissue.

P-Fibrous tissue (dense). 
$\because:$ 


\section{Fibrous Tissue.}

(1) The capsular ligament (dense).

(2) Posterior to head of rib (greatly infiltrated with fat).

(3) The thickened periosteum of posterior surface of first dorsal (dense).

(4) Attached to antero-superior part of nerve (fine).

(5) Inferior to nerve in which vessels are imbedded (dense).

It is more abundant. The capsular ligament is thicker. The tissue posterior to the head of rib and the periosteum posterior to the body of the first dorsal is more abundant. The increased thickness of the periosteum is probably due to the thinness of the bone here. The fibrous coats of the blood vessels inferior to the nerve are so thick that it appears as if they were embedded in this tissue. This same fibrous tissue is continuous with the capsular ligament posteriorly and the thickened periosteum anteriorly. It is also attached to the pedicle of the second dorsal.

\section{Vacant Spaces.}

(1) Anterior to nerve.

(2) Superior to nerve. 


\section{DESCRIPTION OF PLATE 10 (Section 24)}

This is immediately external to the right first dorsal intervertebral foramen.

\section{The Bony Boundaries External to Intervertebral Foramen}

Anterior $\left\{\begin{array}{l}\text { Part of body of first dorsal (above). } \\ \text { Head of second rib (below). }\end{array}\right.$

Posterior $\left\{\begin{array}{l}\text { Inferior articular process of first dorsal (above). } \\ \text { Superior articular process of second dorsal (be- } \\ \text { low). }\end{array}\right.$

Superior $\{$ Pedicle of first dorsal.

Inferior $\{$ Pedicle of second dorsal.

(In this and all the following plates, the positions of the bony boundaries are named according to their relations to the nervous structures.)

The boundaries are very similar to those of the former plate, except that a small part of the body of the first dorsal which helped form the anterior boundary of the foramen, has disappeared. Therefore, this is not a complete foramen. This plate bears the same relation to the intervertebral foramen as Plate 8 ; both could be considered as in the foramen.

The deficiency of the body of the first dorsal is made up by fibrous tissue and fat cells. The fibrous tissue on the anterior and posterior surfaces of the body of the first dorsal supplies the necessary tissue here. From the fat cells anterior to the body of the same vertebra are derived the necessary cells. A break in the continuity of the pedicle of the second dorsal is noted. This is due to a nutrient foramen in this situation. This foramen leads into the cancellous bone of the pedicle and nourishes it, conveying blood from one of the large vessels situated in the fibrous tissue, inferior to the nerve. 


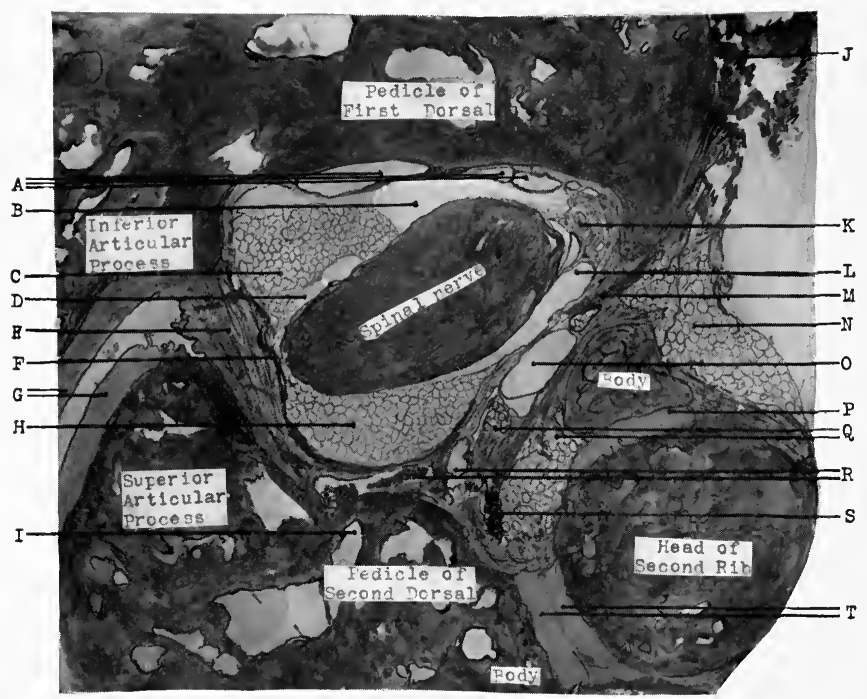

A right lateral view immediately external to the right first dorsal intervertebral foramen.*

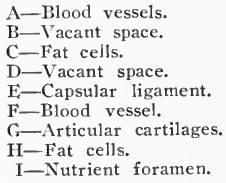

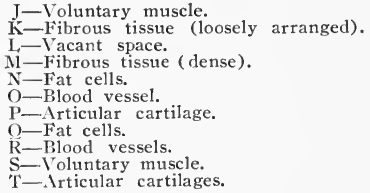

*This plate is so close to the intervertebral foramen that it could almost be considered as in the most external part of the foramen. 

These nutrient foramina are frequently noticed in the pedicles of the upper dorsal vertebrae.

\section{The Articular Cartilage on Bony Boundaries}

Similar to the former plates (see Plate 5)

\section{The Tissues External to Intervertebral Foramen}

1. Nervous Structures.

2. Fat Cells.

3. Blood Vessels.
4. Fibrous Tissue.

5. Vacant Spaces.

6. Voluntary Muscle.

They are similar to the former plate except for the addition of voluntary muscle.

\section{Nervous Structures.}

The spinal nerve.

It resembles the former plate, except that the fibrous tissue in contact with it antero-superiorly is more abundant.

2. Fat Cells.

(1) Postero-superior to nerve.

(2) Inferior to nerve.

(3) Posterior to head of rib.

(4) In the position formerly occupied by body of first dorsal.

(5) In the fibrous tissue inferior to nerve.

There is more fat posterior to the head of the rib. A considerable amount is seen anterior to the body of the first dorsal. This helps to fill in where the bone is deficient. Fat cells have begun to infiltrate the fibrous tissue inferior to the nerve. As a whole the fat is less in amount.

3. Blood Vessels.

(1) Three fair sized ones in fibrous tissue inferior to nerve (all distended).

(2) A small one in capsular ligament (collapsed). 
(3) Several fair sized small ones inferior to pedicle of first dorsal (all distended).

Only three are now seen inferior to the nerve. One gives off a branch which enters the nutrient foramen in the pedicle in this situation. The vessels passing beneath the pedicle of the first dorsal have divided into five and now occupy the entire length of the pedicle.

\section{Fibrous Tissue.}

(1) The capsular ligament (dense).

(2) Attached to antero-superior part of nerve (fine).

(3) Inferior to nerve in which vessels are imbedded (dense).

(4) In the position formerly occupied by body of first dorsal (dense).

The fibrous tissue is further increased in amount. That which is attached to the antero-superior part of the nerve is more abundant. The tissue which helps to make up the deficiency of the body of the first dorsal replaces the thickened periosteum in this situation. Part of it appears folded on itself due to faulty technic. The fibrous tissue posterior to the head of the rib, as seen in the former plates, is entirely replaced by fat cells.

\section{Vacant Spaces.}

(1) Anterior to nerve.

(2) Two superior to nerve.

\section{Voluntary Muscle.}

In the fibrous tissue posterior to head of rib.

This muscle is made up of a small group of fibers, closely collected together and surrounded by. fibrous tissue. They are not attached to bone. Under high magnification they appear striated, hence are voluntary. Passing externally, the muscle steadily increases in amount. 


\section{DESCRIPTION OF PLATE 11 (Section 221/2)}

This is external to the right first dorsal intervertebral foramen, external to Plate 10.

\section{The Bony Boundaries External to Intervertebral Foramen}

Anterior \{ Head of second rib.

Posterior $\left\{\begin{array}{l}\text { Inferior articular process of first dorsal (above). } \\ \text { Superior articular process of second dorsal (be- } \\ \text { low). }\end{array}\right.$

Superior \{ Pedicle of first dorsal.

Inferior $\{$ Pedicle of second dorsal.

The boundaries are very similar to those of the former plate, except that that portion of the body of the first dorsal which helped form the anterior boundary has entirely disappeared. It is replaced principally by fibrous tissue. The nutrient foramen is present in the pedicle of the second dorsal.

\section{The Articular Cartilages on Bony Boundaries}

1. Inferior articular process of first dorsal.

2. Superior articular process of second dorsal.

3. Body of second dorsal.

4. Head of second rib.

On account of the body of the first dorsal no longer being present, the cartilage on it and on that part of the head of the rib, with which it articulates, is no longer seen. The other bones have cartilage as in the former plates. 


\section{The Tissues External to Intervertebral Foramen}

Similar to the former plate (Plate 10)

\section{Nervous Structures.}

The spinal nerve.

It appears somewhat closer to the pedicle of the first dorsal, otherwise there is no change.

2. Fat Cells.

(1) Posterior-superior to nerve.

(2) Inferior to nerve.

(3) Posterior to head of rib.

(4) In position formerly occupied by body of first dorsal.

(5) In fibrous tissue inferior to nerve.

There are no changes worthy of mention.

\section{Blood Vessels.}

(1) Two large ones in the fibrous tissue inferior to nerve (distended).

(2) A small one in capsular ligament (collapsed).

(3) Several fair sized and small ones inferior to pedicle of first dorsal (all distended).

These vessels, which pass inferior to the pedicle of the first dorsal, now seem so numerous that they reach around and become continuous with the blood vessel in the capsular ligament. The large vessels in the fibrous tissue inferior to the nerve are reduced to two, neither of which appears to enter the nutrient foramen in the pedicle of the second dorsal.

\section{Fibrous Tissue.}

(1) The capsular ligament (dense).

(2) Attached to antero-superior part of nerve (fine).

(3) Inferior to nerve in which vessels are imbedded (dense). 


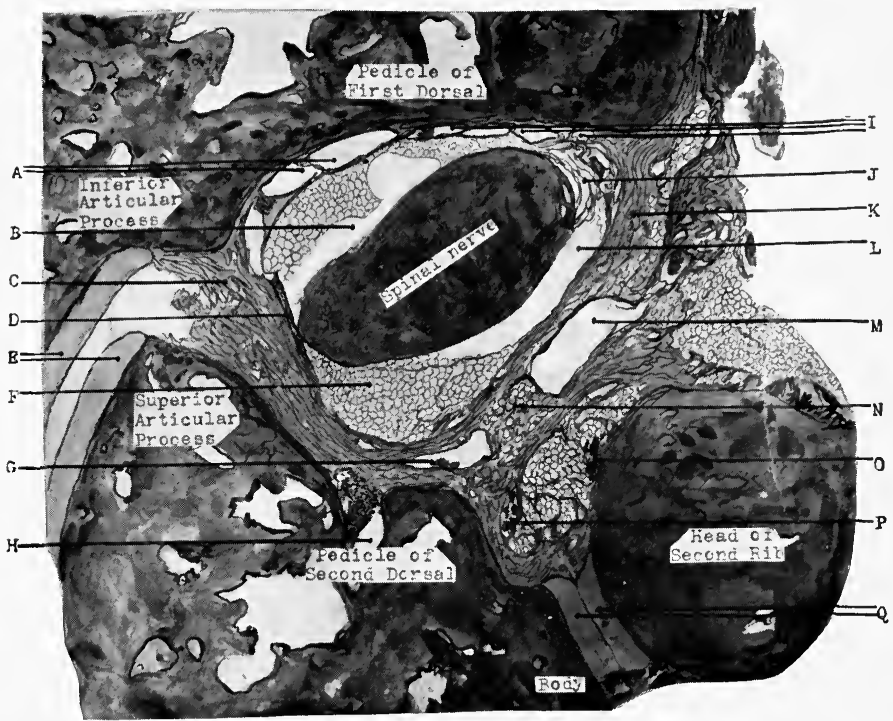

A right lateral view external to the right first dorsal intervertebral foramen immediately external to Plate 10.

A-Blood vessels.

B-Wacant space.

C-Capsular ligament.

D-Blood vessel.

E-Articular cartilages.

F-Fat cells.

G-Blood vessel.

H-Nutrient foramen.
I-Blood vessels.

J-Fibrous tissue (loose).

K-Fibrous tissue (dense).

I-Vacant space.

II-Blood vessel.

$\mathrm{N}$-Fatty-fibrous tissue.

O-Voluntary muscle.

P-Voluntary muscle.

Q-Articular cartilages. 
(4) In the position formerly occupied by body of first dorsal (dense).

Fibrous tissue almost entirely fills the position formerly occupied by the body of the first dorsal. This tissue is continuous with the fibrous tissue inferior to the nerve in which the blood vessels are embedded. Like in the former plate, this latter tissue is continuous with the capsular ligament which now appears thicker.

5. Vacant Spaces.

(1) Anterior and inferior to nerve.

(2) Superior to nerve.

6. Voluntary Muscle.

(1) Attached to posterior surface of head of rib.

(2) In the fatty-fibrous tissue anterior to body of second dorsal.

It is increased in amount. 


\section{DESCRIPTION OF PLATE 12 (Section 21)}

This is external to the right first dorsal intervertebral foramen, external to Plate 11.

\section{The Bony Boundaries External to Intervertebral Foramen}

Posterior $\left\{\begin{array}{l}\text { Inferior articular process of first dorsal (above). } \\ \text { Superior articular process of second dorsal (be- } \\ \text { low). }\end{array}\right.$ Superior $\{$ Pedicle of first dorsal.

Inferior $\left\{\begin{array}{l}\text { Neck of second rib (in front). } \\ \text { Posterior part of pedicle of second dorsal (behind). }\end{array}\right.$

The neck of the second rib replaces the head of this same bone. This is explained as follows: The neck of the rib is continuous with the head, but is on a more external level; it is only natural since we are passing externally that the neck of the rib replace the head. The reason that the neck is seen more inferior to the nerve is because the rib, from its articulation with the bodies of the first and second dorsal vertebrae, passes inferiorly, posteriorly and externally. It must pass in these directions because it also articulates (the second rib) with the transverse process of the second dorsal. The anterior part of the pedicle of the second dorsal has disappeared, and this accounts for the space seen between the posterior part of the pedicle and the neck of the rib. This space is filled with fat cells, voluntary muscle, and fibrous tissue. This latter tissue connects the posterior part of the pedicle with the posterior surface of the neck of the rib. The reason for the above change in the pedicle is that it runs posterior and external from the body of the vertebra. Therefore, in passing externally, the anterior part of the pedicle is the first to disappear. The nutrient foramen in this pedicle still remains. 


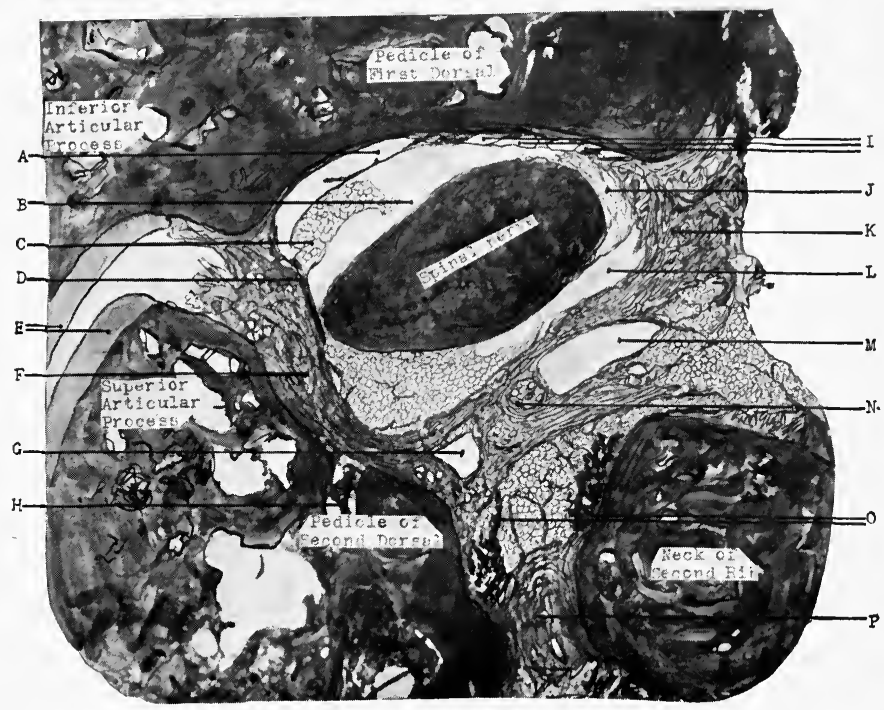

A right lateral view external to the right first dorsal intervertebral foramen, immediately external to Plate 11.

A-Blood vessel.

B-Vacant space.

C-Fat cells.

D-Blood vessel.

E-Articular cartilages.

F-Capsular ligament.

G-Blood vessel.

H-Nutrient foramen.
I-Blood vessels.

J-Fibrous tissue (loose).

$\mathrm{K}$-Fibrous tissue (dense).

L-Vacant space.

M-Blood vessel.

N-Fatty-fibrous tissue.

$\mathrm{O}$-Voluntary muscle.

P-Fibrous tissue (dense). 


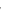




\section{The Articular Cartilages on Bony Boundaries}

1. Inferior articular process of first dorsal.

2. Superior articular process of second dorsal.

The neck of the second rib is not in bony contact with any of the adjacent parts, hence no cartilage is seen on it. The body of the second dorsal has disappeared, so the cartilage present on it in the former plates is, of course, absent.

\section{The Tissues External to Intervertebral Foramen.}

Similar to the former plate (see Plate 10)

\section{Nervous Structures.}

The spinal nerve.

It is the same as in the former plate, except for a slight change in the contour.

\section{Fat Cells.}

(1) Posterior-superior to nerve.

(2) Inferior to nerve.

(3) Posterior to neck of rib.

(4) In position formerly occupied by body of first dorsal.

(5) In the fibrous tissue inferior to nerve.

They are the same as in the former plate.

3. Blood Vessels.

(1) Two large ones in fatty-fibrous inferior to nerve (distended).

(2) A small one in capsular ligament (collapsed).

(3) Several fair sized and small ones inferior to pedicle of first dorsal (all distended).

They are the same as in the former plate. 
4. Fibrous Tissue.

(1) The capsular ligament (dense).

(2) Attached to antero-superior part of nerve (fine).

(3) Inferior to nerve in which the large vessels are imbedded (dense).

(4) In the position formerly occupied by body of first dorsal (dense).

(5) Connecting neck of rib with pedicle of second dorsal (dense).

The only change is (5).

5. Vacant Spaces.

(1) Anterior and inferior to nerve.

(2) Superior to nerve.

6. Voluntary Muscle.

(1) Attached to posterior surface of neck of rib.

(2) In the fatty-fibrous tissue anterior to pedicle of second dorsal and partly attached to it.

It is increased in amount. 
(5) In the fibrous tissue inferior to nerve.

(6) In the capsular ligament.

The fat cells in the fibrous tissue inferior to the nerve have greatly increased. The only other change is the infiltration of fat cells into the capsular ligament.

3. Blood Vessels.

(1) Two fair sized ones in the fatty-fibrous tissue inferior to nerve (distended).

(2) A fair sized one in the capsular ligament (distended).

(3) Several fair sized and small ones inferior to pedicle of first dorsal (distended).

The vessels inferior to the nerve are smaller, those inferior to the pedicle of first dorsal seem to be less in number and empty into the vessel in the capsular ligament or vica versa.

4. Fibrous Tissue.

(1) The capsular ligament (dense).

(2) Inferior to nerve (attached to it at one place) in which some vessels are imbedded (dense).

(3) In position formerly occupied by body of first dorsal (dense).

The tissue attached to the antero-superior part of the nerve and that connecting the pedicle of second dorsal with neck of rib has disappeared. The capsular ligament is thicker. The tissue in the position formerly occupied by the body of first dorsal is less abundant.

5. Vacant Spaces.

(1) Inferior to nerve.

(2) Superior to nerve:

6. Voluntary Muscle.

Between neck of rib and pedicle of second dorsal.

It is further increased in amount. It appears to replace the fibrous tissue connecting the above parts. 


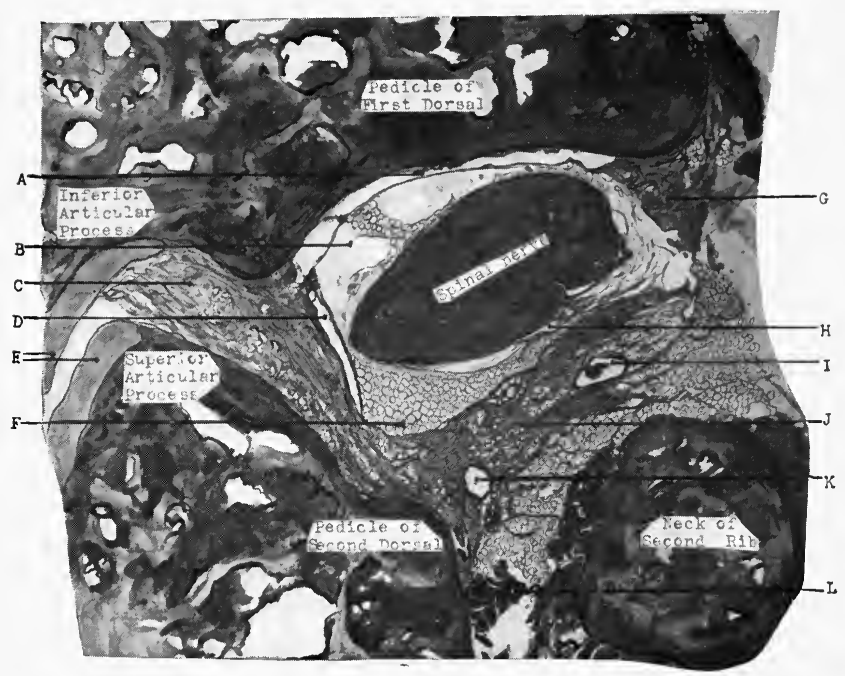

A right lateral view external to the right first dorsal intervertebral foramen, immediately external to Plate 1?.

A-Blood vessel.

B-Vacant space.

C-Capsular ligament.

I)-Blood vessel.

E-Articular cartilages.

F-Fat cells.
$\mathrm{G}$-Fibrous tissue (dense)

$\mathrm{H}-\mathrm{V}$ acant space.

I-Blood vessel.

T-Fatty-fibrous tissue.

K-Blood vessel.

I - Voluntary muscle. 


$$
\text { . }
$$




\section{DESCRIPTION OF PLATE 14 (Section 17)}

This is external to the right first dorsal intervertebral foramen, external to Plate 13.

\section{The Bony Boundaries External to Intervertebral Foramen}

Posterior $\left\{\begin{array}{l}\text { Transverse process of first dorsal (above). } \\ \text { Transverse process of second dorsal (below). }\end{array}\right.$

Superior \{Transverse process of first dorsal.

Inferior $\left\{\begin{array}{l}\text { Neck of second rib (in front). } \\ \text { Transverse process of second dorsal (behind). }\end{array}\right.$

The reason for the transverse processes forming the above relations is because they project externally from the pedicles and articular processes. Being external to the latter parts, it is natural to find the transverse processes.

\section{The Articular Cartilage on Bony Boundaries}

This has entirely disappeared. The bony parts present do not articulate with one another. No cartilage is present in any of the remaining plates.

\section{The Tissues External to Intervertebral Foramen}

Similar to the former plate (see Plate 10)

\section{Nervous Structures.}

The spinal nerve.

It appears comparatively free from the surrounding parts; however, this is no doubt due to faulty technic. Posterior to it a vacant space is seen and the nerve is free. The nerve evidently has been torn from its connection with the fibrous tissue in this situation, for it was attached to it in the former plate, and is also attached in the plates which follow. Anterior to the nerve all tissue has disappeared. 
2. Fat Cells.

(1) Postero-superior to nerve.

(2) Inferior to nerve.

(3) Posterior and superior to neck of rib.

(4) In the fibrous tissue inferior to nerve.

(5) In the fibrous tissue between the transverse processes.

It is markedly noticeable how few fat cells are in contact with the nerve.

\section{Blood Vessels.}

(1) One small one in the fatty-fibrous tissue inferior to nerve (distended).

(2) Two small ones among the fat cells between the transverse process of second dorsal and neck of rib (distended).

(3) Several small ones inferior to transverse process of first dorsal (distended).

The one which was in the capsular ligament has disappeared. The vessels in the fatty-fibrous tissue inferior to the nerve are smaller. Only one of these can now be distinguished. The two vessels seen between the transverse process of second dorsal and neck of the rib have, no doubt, descended there from the fatty-fibrous tissue seen inferior to nerve in the former plate.

\section{Fibrous Tissue.}

(1) Between the transverse processes (loose).

(2) Inferior to nerve (dense).

(3) Antero-superior to nerve (dense).

That which was situated in the position formerly occupied by the body of the first dorsal has disappeared, except for a small amount which is attached to the anterior part of the transverse process of the first dorsal, antero-superior to the nerve. The fibrous tissue inferior to the nerve appears 


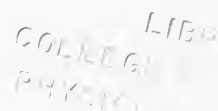

PLATE 14 (Section 17)

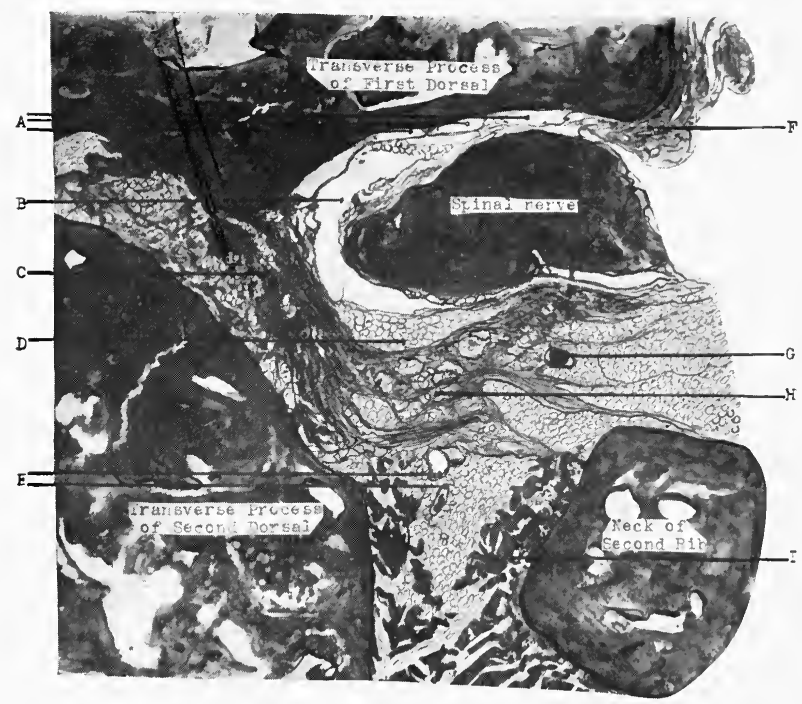

A right lateral view external to the right first dorsal intervertebral foramen, immediately external to Plate 13.

A-Blood vessels.

B-Vacant space.

C-Fatty-fibrous tissue.

D-Fat cells.

E-Blood vessel.
F-Fibrous tissue (dense).

G-Blood vessel.

H-Fatty-fibrous tissue.

I-Voluntary muscle. 


$$
\begin{aligned}
& 90199812+10+102
\end{aligned}
$$

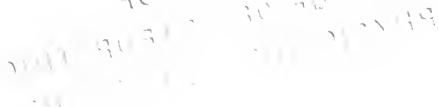


greatly infiltrated with fat cells. The fibrous tissue between the transverse processes replaces the capsular ligament.

\section{Vacant Spaces.}

(1) Posterior to nerve.

(2) Inferior to nerve.

The nerve appears torn from the surrounding fibrous tissue both posteriorly and inferiorly.

6. Voluntary Muscle.

Between the transverse process of second dorsal and neck of rib.

It is further increased in amount, but remains in its old position. 


\section{DESCRIPTION OF PLATE 15 (Section 15)}

This is external to the right first dorsal intervertebral foramen, external to Plate 14.

\section{The Bony Boundaries External to Intervertebral Foramen}

Similar to the former plate (Plate 14)

A nutrient foramen is beginning to form in the transverse process of the first dorsal.

The Tissues External to Intervertebral Foramen

1. Nervous Structures. 4. Fibrous Tissue.

2. Fat Cells.

5. Voluntary Muscle.

3. Blood Vessels.

The vacant spaces have disappeared. This is the only change.

\section{Nervous Structures.}

(1) Anterior and posterior primary divisions of spinal nerve.

(2) White and gray rami communicantes of sympathetic.

The spinal nerve is bifurcated into a large anterior and several small posterior primary divisions. The reasons for the greater difference in size of the divisions was given in the introduction (page 18). A few nerve cells are present in the anterior division. Nerve cells in these plates appear in the spinal ganglion, spinal nerve, and the anterior division of the nerve. This is not the ordinary arrangement for they are usually entirely confined to the spinal ganglion.

Immediately above the middle of the superior part of the anterior division of the spinal nerve, two nervous structures will be noticed. They are either entering or leaving the anterior division, and are the gray and white rami communi- 


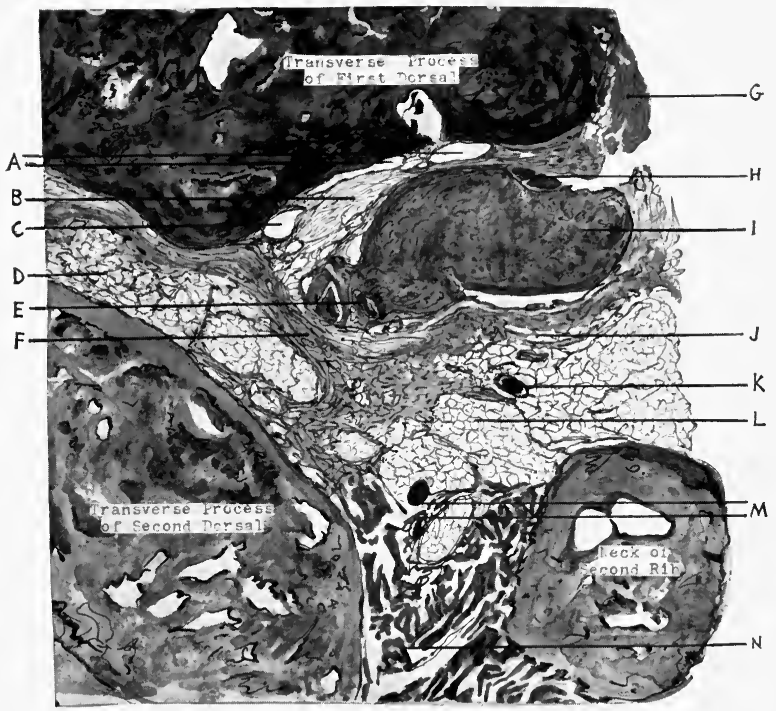

A right lateral view external to the right first dorsal intervertebral foramen, immediately external to Plate 14.

A-Blood vessels.

B-Fibrous tissue (fine).

C-Blood vessel.

D-Fatty-fibrous tissue.

E-Posterior primary divisions of spinal nerve.

F-Fibrous tissue (dense).
G-Fibrous tissue (dense).

H-White and gray rami communicantes of sympathetic.

I- Interior primary division of spinal nerve.

I-Fatty-fibrous tissue.

K-Blood vessel.

L-Fat cells.

II-Blood vessels.

$\mathrm{N}$-Voluntary muscle. 


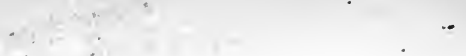


cantes of the sympathetic. They are close together, separated only by a small amount of fibrous tissue. Both are surrounded by a fibrous sheath and are similar in structure. It would be well to recall the histologic structure of these parts. The following is taken from Bailey's Histology: "The fibers of the white rami communicantes are mostly fine and medullated. The axones of the sympathetic cells [this would include the gray rami] are fine and non-medullated or thinly medullated." From this, it can be seen that there is a slight difference in the histologic structure in these two parts. The reason this difference cannot be confirmed in this series is, perhaps, due to the technic required to prepare this specimen. The nitric acid used may be responsible.

The following facts prove the above structures to be the white and gray rami of the sympathetics:

1. Because practically all authorities state that such structures pass to and away from the anterior division of the spinal nerves in the dorsal region.

2. Because they possess that fine histologic structure which is said to be characteristic of these parts. The cerebrospinal nerve fibers are coarser.

3. Because they are so close together. The findings in this respect agree with those of Langley. (See footnote, page 19.)

All the nervous structures are imbedded in fibrous tissue, which, for the most part, is fairly dense, and appears very intimately adherent to the epineurium of the nervous structures. The epineurium is more firmly adherent to the surrounding fibrous tissue than to the nerves. No other tissue is in contact with the nervous structures.

\section{Fat Cells.}

(1) Posterior and superior to neck of rib.

(2) In the fibrous tissue inferior to nervous structures. 
(3) In the fibrous tissue between the transverse processes.

Fat cells no longer are in contact with any of the nervous structures.

\section{Blood Vessels.}

(1) One small one in fatty-fibrous tissue inferior to nervous structures (distended).

(2) Two small ones among fat cells between the transverse process of second dorsal and neck of rib (distended).

(3) Several small ones inferior to transverse process of first dorsal (distended).

The vessels are very similar to the former plate.

\section{Fibrous Tissue.}

(1) Entirely surrounding the nervous structures (dense).

(2) Between the transverse processes (loose).

This tissue has greatly increased in amount. One band of fibrous tissue attaches to the transverse process of the first dorsal posterior to the nervous structures, and passes downward and forward, behind the posterior division of the nerve and becomes continuous with the fibrous tissue inferior to the nervous structures. The band in this situation also has an attachment which connects it to the transverse process of the second dorsal. (This replaces the old capsular ligament.) It then passes inferior to the nervous structures, then anterior to them. Some of this tissue passes superior to the nervous structures and attaches to the inferior surface of the transverse process of the first dorsal. (It is in this fibrous tissue that the white and gray rami are imbedded.) The remaining part of it passes up anterior to the transverse process of the first dorsal to which it is attached. The fibrous tissue appears broken here, which is, no doubt, due to faulty technic. 
The remaining fibrous tissue connects the two transverse processes posteriorly, and in some places is greatly infiltrated with fat. Some areolar tissue is present superior to the posterior primary division of the nerve.

\section{Voluntary Muscle.}

Between the transverse process of second dorsal and neck of rib.

It is further increased in amount, but remains in its old position. 


\section{DESCRIPTION OF PLATE 16 (Section 13)}

This is considerably external to the right first dorsal intervertebral foramen, external to Plate 15.

\section{The Bony Boundaries External to Intervertebral Foramen}

Posterior $\{$ Transverse process of second dorsal.

Superior $\{$ Transverse process of first dorsal.

Inferior $\left\{\begin{array}{l}\text { Neck of second rib (in front). } \\ \text { Transverse process of second dorsal (behind). }\end{array}\right.$

The transverse process of the first dorsal no longer has any part of it posterior to the nervous structures. This is the only change in the bony boundaries. The nutrient foramen in the above transverse processes is fully formed.

\section{The Tissues External to the Intervertebral Foramen}

Similar to the former plate (Plate 15)

\section{Nervous Structures.}

(1) Anterior and posterior primary divisions of spinal nerve.

(2) White and gray rami communicantes of sympathetic.

These are very similar to the former plate. The anterior and posterior divisions appear to be passing a little more anteriorly, for the transverse process of the first dorsal does not cover them superiorly as much as formerly. The sympathetic fibers are still close together but have passed anteriorly and inferiorly and are now imbedded in the fibrous tissue anterior to the anterior division of the nerve. 


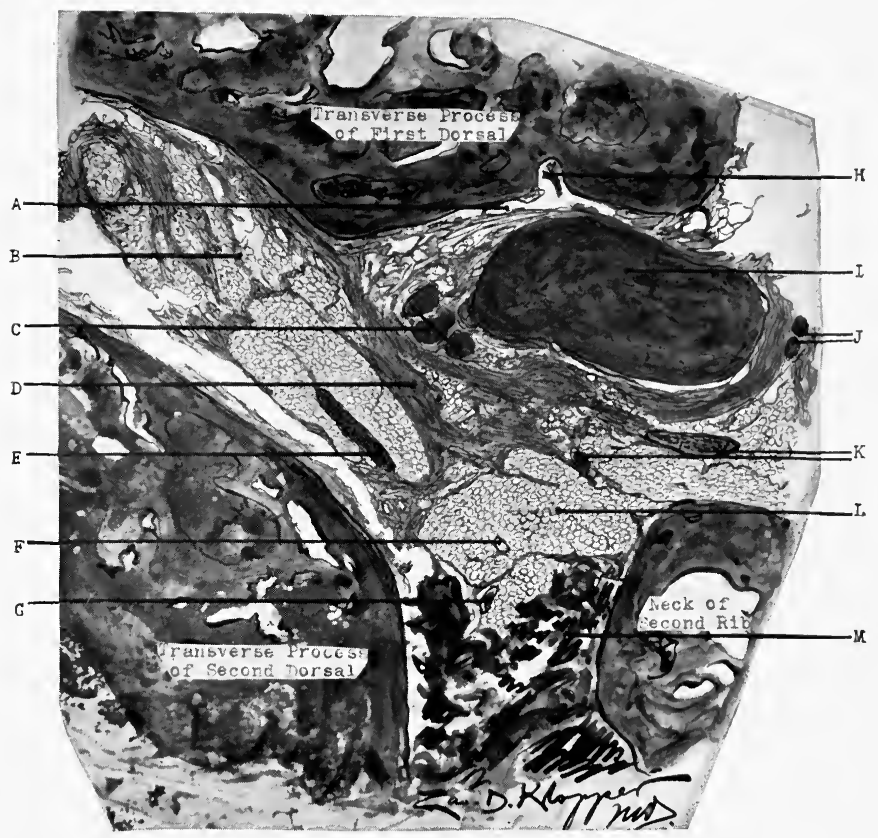

A right lateral view external to the right first dorsal intervertebral foramen, immediately external to Plate 15.

A-Blood vessel.

B-Fatty-fibrous tissue.

C-Posterior divisions of spinal nerve.

D-Fibrous tissue (dense).

E-Blood vessel.

F-Blood vessel.

G-Blood vessel.
H-Nutrient foramen.

I- Interior division of spinal nerve.

J-White and gray rami of sympathetic.

$\mathrm{K}-\mathrm{Blood}$ vessels.

L-Fat cells.

II-Voluntary muscle. 
2. Fat Cells.

(1) Posterior and superior to neck of rib.

(2) In fibrous tissue inferior to nervous structures.

(3) In fibrous tissue between the transverse processes.

They are similar to the former plate.

\section{Blood Vessels.}

(1) One of fair size and a small one in fatty-fibrous tissue inferior to nervous structures (distended).

(2) Two small ones among the fat cells between the transverse process of second dorsal and neck of rib (distended).

(3) Several small ones inferior to transverse process of first dorsal (distended).

(4) One fair sized one among the fat cells between the transverse processes (distended).

The vessel between the transverse processes is a new one. It appears cut almost longitudinally. The fair sized vessel inferior to the nervous structures is also new and appears cut nearly longitudinally. No doubt, both of these vessels are passing in this direction, hence are partly included in this plate.

\section{Fibrous Tissue.}

(1) Entirely surrounding the nervous structures (dense).

(2) Between the transverse processes (loose).

The fibrous tissue surrounding the nervous structures appears broken and is not continuous above the anterior division of the nerve. This is, no doubt, due to faulty technic.

\section{Voluntary Muscle.}

Between the transverse process of second dorsal and neck of rib.

It is still further increased in amount, but remains in its old position. 


\section{SUMMARY}

\section{Nervous Structures and Their Immediate Relations}

Anterior and Posterior Roots (Spinal Ganglion on Posterior Root). The roots are located in the spinal canal being held together by fatty-fibrous tissue and are entirely surrounded by fat cells.

Spinal Nerve. The spinal nerve is formed by the union of the anterior and posterior roots in the spinal canal, or the most internal part of the intervertebral foramen, and passes through the foramen and external to it, where the nerve bifurcates. In the spinal canal it is entirely surrounded by fat cells. In the intervertebral foramen it is almost completely surrounded by fat cells. However, it is in slight contact with the capsular ligament at its postero-inferior part and with some loose fibrous tissue at its antero-superior part. Outside of the intervertebral foramen the nerve is in slight contact with the capsular ligament posteriorly, with fibrous tissue anterosuperiorly, and further externally with fibrous tissue inferiorly. In all other parts it is surrounded by fat cells, except the supero-anterior portion, where the blood vessels which pass inferior to the pedicle separate it from that bone.

Anterior and Posterior Primary Divisions. The spinal nerve bifurcates into these divisions external to the intervertebral foramen. They are completely surrounded by fibrous tissue, which, for the most part, is fairly dense and intimately adherent to the epineurium of the nerves. This tissue is also attached to the two adjacent transverse processes. The nervous structures pass immediately inferior to the transverse process of the upper vertebra and are very close to it. 
White and Gray Rami Communicantes of the Sympathetic. These leave the superior part of the anterior primary division of the nerve, therefore are external to the intervertebral foramen. Being very closely associated, they emerge together. They pass downward, forward and outward, (inferior, anterior and external) anterior to the anterior division of the nerve and are imbedded in the fibrous tissue in that situation. Each ramus has its own epineurium.

Thus we see that fat serves as the principal protective medium for the nervous structures in the spinal canal and intervertebral foramen. Fibrous tissue acts as the main protective agency external to the foramen.

\section{Other Interesting Facts}

Passing externally from the spinal canal it is markedly noticed how the fat tissue decreases in amount. In the spinal canal and the intervertebral foramen, the nervous structures were practically imbedded in this fat tissue, being in actual contact with it. External to the intervertebral foramen, comparatively little fat is seen. In Plates 15 and 16 , the most external, there are no fat cells touching the nervous structures.

Another easily detected change is the increase in fibrous tissue passing externally. In the spinal canal there is no fibrous tissue surrounding the nerves. Of course the epineurium, which is of fibrous tissue, is always present. In the intervertebral foramen the fibrous tissue begins to appear, and outside of the foramen the nervous structures are completely embedded in it.*

In order to fully appreciate the above, compare Plate 5, the most internal, with Plate 16 , the most external. At a glance this comparison shows how the external fibrous tissue

*The term fascia may be supplemented for the fibrous connective tissue external to the intervertebral foramen. 
replaces the internal fatty tissue as the protecting medium of the nervous structures.

Externally the fat has a tendency to get further away from the nervous structures and the fibrous tissue closer to them.

Another interesting fact is the size of the spinal nerve as compared with the intervertebral foramen. This is very well shown in Plate 3, where the foramen is about three times the size of the nerve. The intervertebral disc between the first and second dorsal vertebrae averages approximately $1 \mathrm{~mm}$. in thickness. If the disc should shrink, the foramen would be reduced in size, and this reduction would be principally in a supero-inferior diameter; the pedicles of the two vertebrae tending to approach one another. If it should shrink away entirely, the foramen would be reduced from its normal $4 \mathrm{~mm}$. supero-inferior diameter to about $3 \mathrm{~mm}$. However, even then it would be impossible for the nerve to be pinched by bone.

Should the articular cartilages on the articular processes undergo thinning, the foramen would be actually increased in size. This increase would be principally in an antero-posterior diameter, the distance between the superior articular process of the second dorsal, and the body of the first dorsal being increased on account of the superior articular process passing posteriorly. The thickness of each articular cartilage on these processes is approximately $1 / 4$ of a $\mathrm{mm}$. If they should both undergo complete atrophy the foramen would be actually increased about $1 / 2$ a $\mathrm{mm}$. in its antero-posterior diameter.

From dissection-room observations, I believe I am justified in stating that if any changes occur in the size of the intervertebral discs or the articular cartilages, they have a marked tendency to become thinner rather than thicker. Should both the disc and the articular cartilages undergo thinning at the same time, the foramen would not, in all probability, be decreased as much in size as when the disc itself is thinned. I have seen many ankylosed specimens where the inter- 


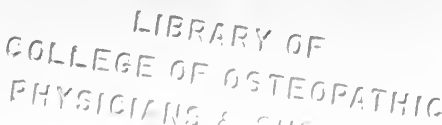

SUMMARY

vertebral foramina have been greatly reduced in size, but in every instance there seemed enough room for the nerve to pass free from any bony pressure. Possibly, in some such cases, the nerve may be subject to actual bony pressure, but from my observations, this occurrence is extremely rare.

Remember, the nervous structures in the spinal canal and intervertebral foramen are embedded in fat. This tissue in the living subject is in a semi-fluid condition. Thus we see that the nervous structures are embedded in a semi-fluid substance, one of the body's best protective agencies. The nerves being composed of such a highly specialized tissue, and therefore so vital, nature seems to use every possible precaution to protect them from bony pressure. This is the reason, no doubt, that the intervertebral foramina, in both animal and man, are so much larger than the nerves themselves. 
$9147.40=72070=195.1100$

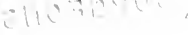



- 


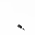

n. 


\section{Date Due}

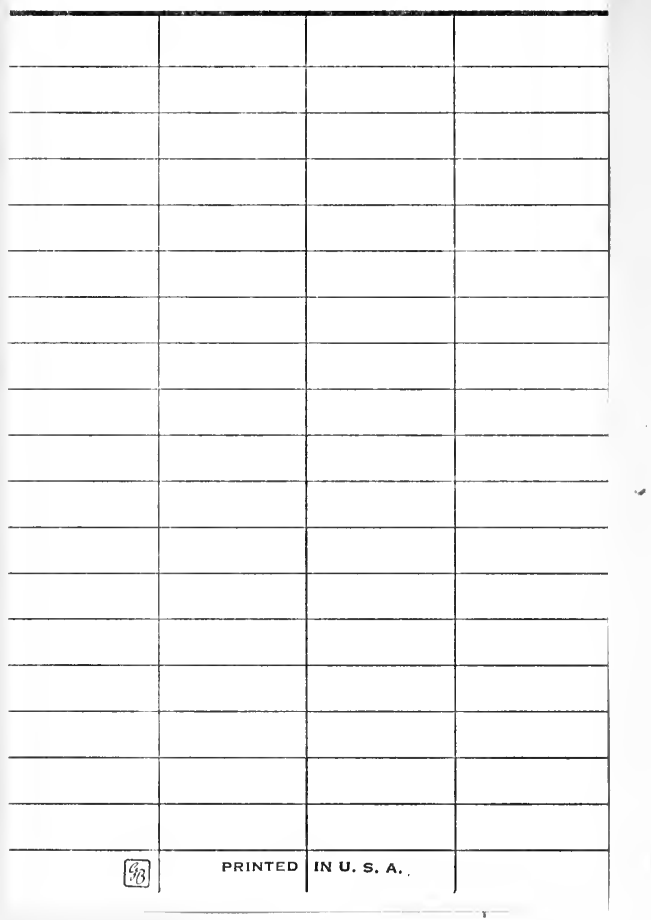




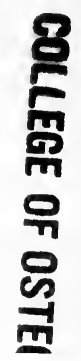

WE 725

S $972 i$

1914

c. 1

Swanberg: the intervertebral foramen

\section{UCI CCM LIBRARY}




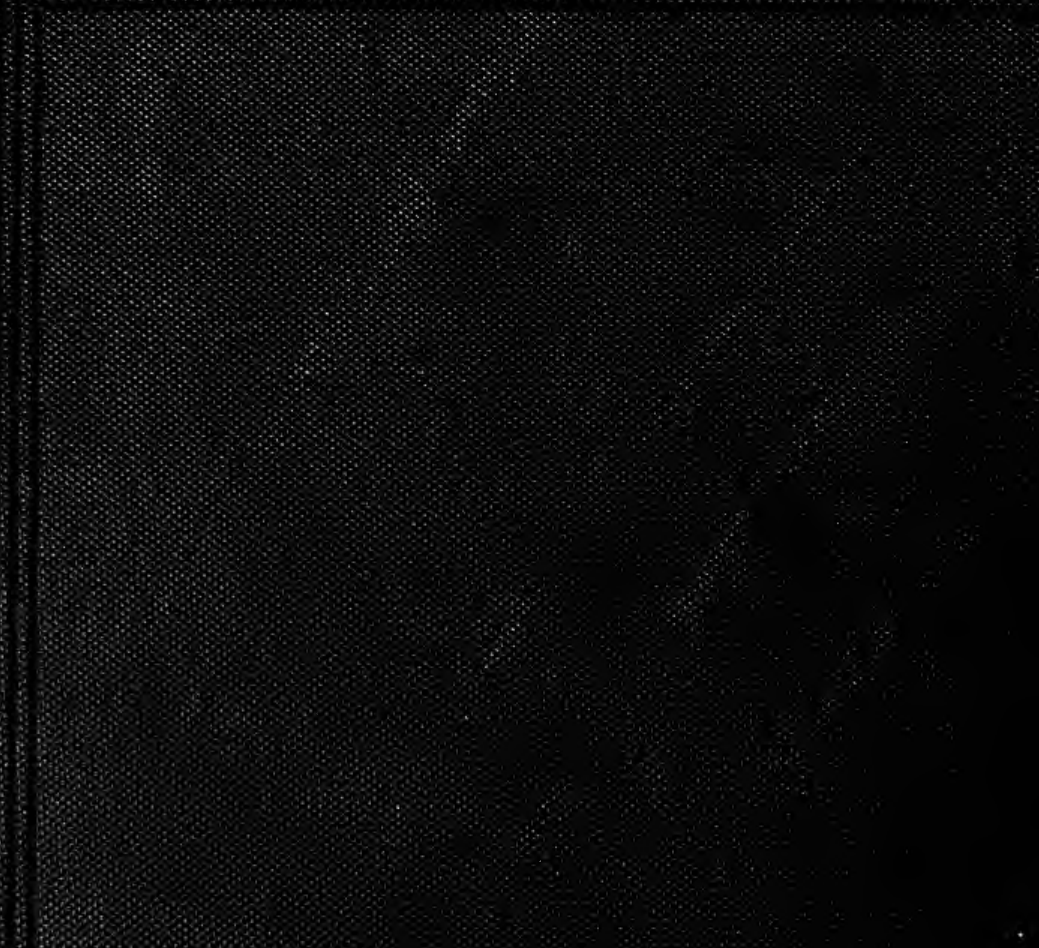

